\title{
Interleukin-10 Is Produced by a Specific Subset of Taste Receptor Cells and Critical for Maintaining Structural Integrity of Mouse Taste Buds
}

\author{
Pu Feng, Jinghua Chai, Minliang Zhou, Nirvine Simon, Liquan Huang, and Hong Wang \\ Monell Chemical Senses Center, Philadelphia, Pennsylvania 19104
}

\begin{abstract}
Although inflammatory responses are a critical component in defense against pathogens, too much inflammation is harmful. Mechanisms have evolved to regulate inflammation, including modulation by the anti-inflammatory cytokine interleukin-10 (IL-10). Previously we have shown that taste buds express various molecules involved in innate immune responses, including the proinflammatory cytokine tumor necrosis factor (TNF). Here, using a reporter mouse strain, we show that taste cells also express the anti-inflammatory cytokine IL-10. Remarkably, IL-10 is produced by only a specific subset of taste cells, which are different from the TNF-producing cells in mouse circumvallate and foliate taste buds: IL-10 expression was found exclusively in the G-protein gustducin-expressing bitter receptor cells, while TNF was found in sweet and umami receptor cells as reported previously. In contrast, IL-10R1, the ligand-binding subunit of the IL-10 receptor, is predominantly expressed by TNF-producing cells, suggesting a novel cellular hierarchy for regulating TNF production and effects in taste buds. In response to inflammatory challenges, taste cells can increase IL-10 expression both in vivo and in vitro. These findings suggest that taste buds use separate populations of taste receptor cells that coincide with sweet/umami and bitter taste reception to modulate local inflammatory responses, a phenomenon that has not been previously reported. Furthermore, IL-10 deficiency in mice leads to significant reductions in the number and size of taste buds, as well as in the number of taste receptor cells per taste bud, suggesting that IL-10 plays critical roles in maintaining structural integrity of the peripheral gustatory system.
\end{abstract}

Key words: cytokines; inflammation; taste buds

\section{Introduction}

Taste receptor cells are exposed to the oral cavity and thus face great challenges from potential pathogens. Recent studies suggest that taste cells are equipped with various immune mechanisms, especially those involved in innate defense responses. These include pattern recognition receptors and their corresponding adaptor proteins, cytokines and chemokines and their receptors, and components of the complement system (Wang et al., 2007, 2009a; Hevezi et al., 2009; Cohn et al., 2010; Feng et al., 2012). However, how defense responses are regulated in taste buds and how they may affect taste bud structure and function remains largely unclear.

Our recent studies found that a subset of taste bud cells, those that express the taste receptor T1R3, produce the proinflammatory cytokine tumor necrosis factor (TNF). Under inflammatory

\footnotetext{
Received July 19, 2013; revised Dec. 17, 2013; accepted Jan. 11, 2014.

Author contributions: P.F., L.H., and H.W. designed research; P.F., J.C., M.Z., N.S., and H.W. performed research; P.F., L.H., and H.W. analyzed data; P.F., L.H., and H.W. wrote the paper.

This study was supported by National Institutes of Health/National Institute of Deafness and Other Communication Disorders grants DC010012 (H.W.), DC007487 (L.H.), and P30 DC011735 and by the National Science Foundation Grant DBJ-0216310. We thank Drs. Gary Beauchamp and Paul Breslin for critical reading of this manuscript and Dr. Karen Yee for technical advice.

The authors declare no competing financial interests.

Correspondence should be addressed to either Pu Feng or Hong Wang, Monell Chemical Senses Center, 3500 Market Street, Philadelphia, PA 19104. E-mail: pfeng@monell.org or hwang@monell.org.

DOI:10.1523/JNEUROSCI.3074-13.2014

Copyright $\odot 2014$ the authors $\quad 0270-6474 / 14 / 342689-12 \$ 15.00 / 0$
}

conditions, such as when challenged with bacterial lipopolysaccharide (LPS), these cells substantially increase TNF production (Feng et al., 2012). However, excessive production of inflammatory cytokines is likely destructive to taste buds as it is to various other organs and tissues (Shoelson et al., 2006; Zipp and Aktas, 2006). Mechanisms to downregulate inflammatory cytokine production should be crucial to protect taste tissues from damage by undue immune responses.

One possible such mechanism is regulation via interleukin-10 (IL-10), an anti-inflammatory cytokine associated with immunological tolerance and suppression. A wide variety of immune cells have been identified as IL-10-producing cells (Saraiva and O'Garra, 2010). Some nonimmune cells, such as gut epithelial cells and keratinocytes, have also been reported to produce IL-10 (Michel et al., 1997; Autschbach et al., 1998). Similarly, IL-10 receptors are expressed by many cell types to mediate the effects of IL-10 on target cells (Moore et al., 2001). As an antiinflammatory cytokine, IL-10 inhibits the production of various proinflammatory cytokines, including TNF. Loss of IL-10 function in mice leads to the development of chronic enterocolitis with pathological gut inflammation (Kühn et al., 1993).

To understand how inflammatory responses are regulated in taste buds, here we investigated the expression and production of IL-10 in taste buds using an IL-10 reporter mouse strain. IL-10 expression was found exclusively in a subset of type II taste cells that express the G-protein gustducin. In contrast, expression of 
IL-10R1, the ligand-binding subunit of the IL-10 receptor, was found preferentially in T1R3-expressing taste cells, the specific subset of taste cells that produces TNF in taste buds. In response to inflammatory challenges, taste cells can greatly increase IL-10 expression. To explore the potential roles of this local IL-10/IL$10 \mathrm{R}$ signaling pathway in taste buds, we examined taste bud structures in $I L-10^{-/-}$mice and found that IL-10 deficiency led to significant reductions in the number and size of taste buds and the number of cells per bud. This study revealed a novel pathway for interaction of taste cells via cytokines and their receptors and provides a useful model for studying the relationship and regulation of IL-10, TNF, and other cytokines in the unique microenvironment of taste buds.

\section{Materials and Methods}

Animals. Six- to eight-week-old adult male or female C57BL/6 (B6) mice were obtained from the The Jackson Laboratory and maintained at the Monell Chemical Senses Center animal facility. IL-10-green fluorescent protein (GFP) mice were generated at Howard Hughes Medical Institute, Yale University School of Medicine (Kamanaka et al., 2006), and obtained from the The Jackson Laboratory. An internal ribosome entry site (IRES)-GFP cassette followed by a loxP-flanked neomycin resistance cassette was inserted between the stop codon and polyadenylation signal of exon 5 of the IL-10 gene. GFP fluorescence in cells from these mice was found to correlate with IL-10 protein expression (Kamanaka et al., 2006). $I L-10^{-I-}$ mice, obtained from the The Jackson Laboratory, carried a targeted mutation of the $I L-10$ gene (Kühn et al., 1993). The mutant mice had been backcrossed to C57BL/6 genetic background for 13 generations and were housed under a specific pathogen-free condition at the time of purchase. After purchase, mice were housed and maintained in strict accordance with the guidelines for the management of laboratory animals at the Monell Chemical Senses Center animal facility (a conventional animal care facility, not a pathogen-free facility). The animals were housed three to four per cage, maintained in a room under a $12 \mathrm{~h} \mathrm{light/}$ dark cycle, and given standard rodent food (8604 Teklad rodent diet; Harlan Laboratories) and water ad libitum. Mice were killed by carbon dioxide asphyxiation. All procedures followed the protocols approved by the Institutional Animal Care and Use Committee of the Monell Chemical Senses Center.

Reagents. A goat polyclonal antibody against mouse TNF- $\alpha$ was purchased from R\&D Systems (Cohn et al., 2010; Feng et al., 2013). Rabbit polyclonal antibody against mouse ectonucleotidase nucleoside triphosphate diphosphohydrolase 2 (ENTPDase2) was purchased from Centre de Recherché (Quebec, Canada; Bartel et al., 2006). Rabbit polyclonal antibodies against phospholipase C- $\beta 2$ (PLC- $\beta 2$, sc-206; Clapp et al., 2001), gustducin (sc-395; Clapp et al., 2001), and IL-10R2 (sc-69579) and goat polyclonal antibodies against T1R3 (Daly et al., 2012) and KCNQ1 (Wang et al., 2009b) were purchased from Santa Cruz Biotechnology. An affinity-purified goat polyclonal antibody against carbonic anhydrase 4 (CA4) was purchased from R\&D Systems (Chandrashekar et al., 2009; Kataoka et al., 2012). Rabbit polyclonal antibodies against polycystic-kidneydisease-2-like-1 (PKD2L1; Gao et al., 2009), KCNQ1 (Wang et al., 2009b), and IL-10R1 (Sasayama et al., 2012) were purchased from Millipore. DyLight 649 (or DyLight 488)-conjugated donkey antirabbit or anti-goat antibodies were purchased from Jackson ImmunoResearch Laboratories. Collagenase A and dispase II were from Roche Applied Sciences. A mouse monoclonal antibody against $\beta$-actin (Wang et al., 2007; Li et al., 2013) and LPS (from E. coli O111:B4) were purchased from Sigma. Staphylococcal enterotoxin A (SEA) was purchased from Toxin Technology.

Immunohistochemistry. Tissue preparation and immunostaining procedures were described previously (Wang et al., 2007; Feng et al., 2012). Briefly, excised mouse tongue tissues were fixed in freshly prepared $4 \%$ paraformaldehyde (PFA) in PBS for $1 \mathrm{~h}$ on ice and then cryoprotected in $20 \%$ sucrose/PBS solution at $4^{\circ} \mathrm{C}$ overnight and embedded in OCT mounting medium. Tissues were sliced into $10-\mu \mathrm{m}$-thick sections using a Microm HM 500 OM cryostat (Thermo Scientific Microm). Circumvallate and foliate sections were cut in parallel to the surface of the tongue. Fungiform sections were collected from the tip of the tongue, which was cut coronally. Spleen, heart, liver, kidney, brain, and gut were processed in the same procedure. IL-10 protein expression in all the examined tissues of IL-10-GFP mice was visualized by intrinsic fluorescence of GFP using a Leica confocal microscope. To detect the cell types that express IL-10 in taste buds, the following primary antibodies against taste cell markers were applied on the tissue sections from IL-10-GFP mice: PLC- $\beta 2$ (1:500), CA4 (1:500), PKD2L1 (1:500), ENTPDase2 (1: $500)$, gustducin (1:1000), or T1R3 (1:500). For immunostaining, the tissue sections were washed $3 \times$ with PBS containing $0.3 \%$ Triton X-100 and then incubated in the blocking buffer ( $3 \%$ bovine serum albumin, $0.3 \%$ Triton $\mathrm{X}-100,2 \%$ horse serum, and $0.1 \%$ sodium azide in PBS) at room temperature for $1 \mathrm{~h}$. The sections were then incubated with the aforementioned primary antibodies in the blocking buffer at $4^{\circ} \mathrm{C}$ overnight and then incubated with DyLight 649-conjugated donkey anti-goat or anti-rabbit antibodies at room temperature for $1 \mathrm{~h}$. For immunostaining of TNF- $\alpha$, a permeabilization buffer containing $0.1 \%$ saponin and $0.009 \%$ sodium azide (eBioscience) was applied at room temperature for $1 \mathrm{~h}$, followed by tissue blocking. The sections were then incubated with affinity-purified goat antibody against TNF- $\alpha$ (1:200) in the blocking buffer containing $0.1 \%$ saponin at $4^{\circ} \mathrm{C}$ overnight and then incubated with DyLight 649-conjugated donkey anti-goat antibody at room temperature for $1 \mathrm{~h}$. For control experiments, nonspecific normal goat and rabbit IgG or blocking buffer was used to replace the corresponding specific primary antibodies. Fluorescent images were acquired using Leica $\mathrm{Sp} 2$ confocal microscope.

To investigate lymphocyte infiltration in taste tissues, we performed immunohistochemistry using an anti-CD3 antibody following the procedures described previously (Feng et al., 2009, 2010). Briefly, frozen sections were incubated with an anti-CD3 antibody and then with a biotinylated secondary antibody. Streptavidin-conjugated horseradish peroxidase (HRP) was then added to the sections. Immunoreactivity to the anti-CD3 antibody was detected using diaminobenzidine as the chromogen. Controls for nonspecific binding were performed by excluding primary antibody. Populations of CD3-immunoreactive cells in both the taste epithelium and the lamina propria underneath the taste epithelium were quantitatively measured using Image-Pro Plus image analysis software (version 6.0; Media Cybernetics). The cell population was expressed as the ratio of the stained area (cells) to the total area of tissue region measured.

IL-10 mRNA in situ hybridization. Digoxigenin (DIG)-labeled sense and antisense cRNA probes corresponding to the coding region of mouse $I L-10$ were synthesized using the DIG RNA labeling kit (Roche Applied Science). Fresh-frozen taste sections (10 $\mu \mathrm{m} / \mathrm{section})$ from IL-10-GFP mice were attached to clean glass slides and processed for in situ hybridization as described previously (Wang et al., 2007). Briefly, after $10 \mathrm{~min}$ fixation using 4\% PFA, GFP fluorescent signals in taste buds were recorded using a Nikon fluorescence microscope. Hybridizations were performed at $72^{\circ} \mathrm{C}$ overnight with DIG-labeled probes in $50 \%$ formamide, $5 \times$ SSC, $5 \times$ Denhardt's solution, $250 \mu \mathrm{g} / \mathrm{ml}$ yeast RNA, and $500 \mu \mathrm{g} / \mathrm{ml}$ sperm DNA. Sections were washed three times at $72^{\circ} \mathrm{C}$ with $0.2 \times$ SSC. Hybridized DIG-labeled cRNA was detected immunologically with an alkaline phosphatase-conjugated anti-DIG antibody and standard chromogenic substrates 4-Nitro Blue tetrazolium chloride (Roche Applied Science). Images were taken using a Nikon fluorescence microscope. In situ hybridization and GFP overlay images were generated using Corel PHOTO-PAINT X6. In all the experiments, hybridizations to antisense and sense probes were performed in parallel to verify the specificity of hybridization signals.

Taste cell counting. Counting of different types of taste cells was performed as described previously (Feng et al., 2012; Kim et al., 2012). In brief, to quantify the number of IL-10-producing cells in taste tissues, two to four circumvallate sections at the middle ranges of the papillae, separated from each other by at least $40 \mu \mathrm{m}$ (four $10-\mu \mathrm{m}$ thick sections away) to avoid double counting of any cells, were selected for immunostaining from serial sections of each papillae from IL-10-GFP mice. Nuclear staining with 4',6-diamidino-2-phenylindole 
(DAPI) was performed to help distinguish individual taste cells. The numbers of IL-10-producing cells and gustducin-positive cells were counted from confocal images. In detail, gustducin-positive cells and IL-10-producing cells were counted from single-channel images, and the gustducin/IL-10 double-positive cells were counted from overlay (or merged) images. The summed and averaged numbers of positive cells from all examined sections of each mouse were defined as a representative value for that individual mouse. Only cells with staining clearly above the background and with morphology of taste cells (spindle shaped) and nuclei (based on DAPI staining) were counted as positive cells. The percentage of IL-10-producing cells among gustducin-positive cells was then calculated. Three to four mice were included in each group.

To quantify the numbers of gustducin-, T1R3-, and CA4-positive cells in taste buds, we conducted double immunostaining on $I L-10^{-1-}$ or wild-type mice by using KCNQ1 antibodies to label all taste cells and to show the outline of the taste buds and using specific antibodies to other taste cell markers to identify cells of interest. Quantification of different types of taste receptor cells was performed as described above. Four to five mice were included in each group.

To compare the number of taste cells in circumvallate taste buds of $I L-10^{-I-}$ mice and wild-type control mice, we conducted immunostaining on circumvallate sections using an anti-KCNQ1 antibody to visualize taste buds and used DAPI staining to visualize nuclei. All nuclei in taste bud profiles with typical morphology (with clear taste pores and the base of taste buds reaching the basement membrane) were counted and recorded. The average number of nuclei per taste bud profile of each mouse was used to represent the number of taste cells per taste bud profile of that individual mouse. Five to six mice were included in each group. The persons who performed cell counting were unaware of the experimental groups.

Fluorescence intensity quantification. To quantitatively compare the expression levels of IL-10-GFP in taste buds, we used Las NF Lite image analysis software. This software allows selection of the area of interest (AOI) on any of the channels of multiple-channel images and automatically measures intensities for each of the channels in the same AOI. All images were analyzed by the same person. The results are presented as gray values.

Measurement of taste bud number and size. To enumerate the numbers and measure the size of circumvallate taste buds in $I L-10^{-1-}$ and wild-type control mice, we selected circumvallate sections from the middle of the papilla with the same or similar serial numbers from each mouse to minimize possible variations in taste bud number and size at different positions of taste papillae. To ensure that a taste bud was not represented twice in the data, adjacent sections were never selected for the analysis and the chosen sections were spaced by at least $40 \mu \mathrm{m}$. The taste bud outline was visualized using anti-KCNQ1 antibodies and fluorescence-conjugated secondary antibodies. For counting taste bud number, all recognizable taste buds based on KCNQ1 immunostaining were included. Measurement of taste bud size was performed as described previously (Kim et al., 2012). To avoid biases of taste buds cutoff-center, only the taste buds with typical morphology (with clear taste pores and the base of taste buds reaching the basement membrane) were included, and at least five taste buds were selected from each section. The averaged area from the selected taste buds was defined as the representative value for that individual mouse. Measurement was done using Las NF Lite image analysis software. Four to five mice per group were included.

Quantitative reverse-transcription PCR. Quantitative reverse-transcription PCR (qRT-PCR) was performed as described previously (Wang et al., 2007; Feng et al., 2012). For tissue collection, freshly excised tongues were rinsed $3 \times$ in $\mathrm{Ca}^{2+}$-free Tyrode's solution containing (in $\mathrm{mm}): 140 \mathrm{NaCl}, 5 \mathrm{KCl}, 10 \mathrm{HEPES}, 1 \mathrm{MgCl}_{2}, 10$ glucose, $10 \mathrm{Na}$-pyruvate, and 2 EGTA, $\mathrm{pH} 7.4$, injected with an enzyme solution $\left(2 \mathrm{mg} \mathrm{ml}^{-1}\right.$ dispase II, $1 \mathrm{mg} \mathrm{ml}^{-1}$ collagenase $\mathrm{A}$ in $\mathrm{Ca}^{2+}$-free Tyrode's solution) beneath the epithelium, and incubated at $37^{\circ} \mathrm{C}$ for $15-20 \mathrm{~min}$. The whole epithelium was then peeled off the tongue and rinsed $3 \times$ in Tyrode's solution on ice. The circumvallate and foliate epithelia containing taste buds were excised carefully from the nongustatory epithelia and placed immediately in the lysis buffer for RNA preparation and qRT-PCR analysis.

Total RNA was extracted using Absolutely RNA Microprep Kit (Stratagene). Epithelial pieces containing foliate and circumvallate taste buds from three mice in each group were pooled as the taste epithelium sample. Approximately equal amounts of total RNA from these samples were reverse transcribed into cDNA using oligo (dT) primers and Superscript III reverse transcriptase (Life Technologies). qPCR was set up using Power SYBR Green PCR Master Mix (Applied Biosystems) and analyzed on an ABI PRISM 7000 Sequence Detection System (Applied Biosystems). Relative quantification of gene expression was performed using ABI software, which was based on the $2^{-\Delta \Delta C t}$ method (Livak and Schmittgen, 2001). In brief, the method normalizes the expression levels of genes of interest against those of "housekeeping" genes in the same samples and then compares relative expression levels among control and treatment samples. $\beta$-Actin was used as the endogenous "housekeeping" control gene for these analyses. The gene expression levels of target genes in the control sample were designated as 1 . The relative gene expression levels in treatment samples were determined as fold differences to the control sample. The experiments were repeated three times. RT-PCR primers for IL-10 were as follows: forward, AAGGCAGTGGAGCAGGTGAA, and reverse, CCAGCAGACTCAATACACAC. Primers for GFP were as follows: forward, TTCAAGGAGGACGGCAACAT, and reverse, GTTCTGCTGGTAGTGGTCGG. Primers for TNF were as follows: forward, CCACATCTCCCTCCAGAAAAGA, and reverse, GCTGGGTAGAGAATGGATGAAC. Primers for IL-10R2 were as follows: forward, TTTGTCGTGCTGTGGCTCAT, and reverse, AGGGAAGGAG AACAGCAGAA. Primers for $\beta$-actin were as follows: forward, GATTACTGCTCTGGCTCCTA, and reverse, ATCGTACTCCTGCTTGCTGA. Primer design was performed using Oligo Explorer software (Softpedia). Forward and reverse primers for each gene were selected from different exons to minimize amplification from genomic DNA. Melting curve analyses were performed to verify the purity of PCR products. The size of DNA products was confirmed by gel electrophoresis.

Western blot analyses. Mouse lingual epithelium was freed from the rest of the tongue as described above. Taste epithelium containing fungiform, foliate, and circumvallate taste buds and a piece of control epithelium devoid of taste buds were collected from each mouse. Tissues from three to four mice were pooled together for sample preparation in Laemmli sample buffer (Bio-Rad). Protein electrophoresis and Western blotting were performed as described previously (Wang et al., 2007; Li et al., 2013). Briefly, protein samples were run on $4-15 \%$ mini-PROTEAN TGX gels (Bio-Rad). Western blots were incubated with a rabbit anti-IL10R2 antibody and a mouse monoclonal antibody against $\beta$-actin (Wang et al., 2007). The secondary antibodies were HRP-conjugated anti-rabbit or anti-mouse antibodies. Pierce ECL 2 Western blotting substrate (Thermo Scientific) was used for detection. Western blots were scanned using Typhoon 9400 Imager (GE Healthcare).

Stimulation of IL-10 or TNF expression in vivo. IL-10-GFP mice were injected intraperitoneally with SEA to stimulate IL-10 expression. Each mouse was injected three times with $5 \mu \mathrm{g}$ of SEA dissolved in $200 \mu \mathrm{l}$ of PBS at 2 d intervals as described previously (Kamanaka et al., 2006). Control mice were injected with the same volume of PBS. Taste tissues were collected $4 \mathrm{~h}$ after final injection for immunostaining or for RNA isolation. Serum was also collected for IL-10 measurement by ELISA (Bosschaerts et al., 2011). qRT-PCR was performed as described above.

C57BL/6 mice and IL-10-GFP were injected intraperitoneally with LPS at a dose of $5 \mathrm{mg} / \mathrm{kg}$ body weight. Taste tissues were collected $3 \mathrm{~h}$ post injection for RNA isolation as described above. For the controls, the same volume of PBS was injected.

To study the response of $I L-10^{-1-}$ mice to inflammatory challenges, we injected $I L-10^{-1-}$ mice and wild-type C57BL/6 mice intraperitoneally with LPS at a dose of $0.5 \mathrm{mg} / \mathrm{kg}$ body weight. For the controls, the same volume of PBS was injected. Taste tissues were collected $16 \mathrm{~h}$ or $5 \mathrm{~d}$ post injection for RNA isolation and qRT-PCR analysis.

IL-10 secretion by cultured taste epithelium and measurement of IL-10 level by ELISA. Isolated foliate and circumvallate taste bud-containing epithelia from three mice in each group were pooled as the taste epithelium sample. The same amount of peeled-off nontaste epithelium from 
the same animals (excised from the back of the tongue) was also collected as nontaste tissue control. To minimize microbial contamination, the collected tissues were incubated for 20 min on ice in DMEM containing $5 \times$ Antibiotic-Antimycotic solution (Invitrogen). Following $3 \times$ washes in DMEM, the tissues were cultured at $37^{\circ} \mathrm{C}$ in DMEM containing $10 \%$ fetal bovine serum and $1 \times$ AntibioticAntimycotic in a $5 \% \mathrm{CO}_{2}$ atmosphere. LPS (5 $\mu \mathrm{g} \mathrm{ml}^{-1}$ ) was added to the treatment group. The supernatants were collected at designated time points and were stored at $-80^{\circ} \mathrm{C}$ before ELISA.

Levels of IL-10 in serum and culture supernatants were measured by ELISA, using Quantikine Mouse IL-10 Immunoassay kit (R\&D Systems) according to the manufacturer's recommendations. Briefly, samples were loaded to the microplate wells in duplicates in $100 \mu \mathrm{l}$ assay diluent, and the plates were incubated at room temperature for $2 \mathrm{~h}$. Serial twofold dilutions of recombinant IL-10 were included as standards. A $100 \mu$ l volume of IL-10 conjugate was added to each well and incubated for $2 \mathrm{~h}$ at room temperature. After washing, $100 \mu \mathrm{l}$ of substrate solution was added to each well and the plate was allowed to develop at room temperature for $30 \mathrm{~min}$ in dark. The reaction was stopped by addition of stop solution. The optical density value at $450 \mathrm{~nm}$ was measured using Flex Station 2. IL-10 concentrations in different groups were determined by comparison with the standard curve.

Statistical analysis. The numbers of animals used for different experiments are described above and in the figure legends. Calculations for quantitative data were performed in Microsoft Excel or GraphPad PRISM computer program (GraphPad Software). Averaged data are presented in graphs as mean \pm SD. Twotailed unpaired Student's $t$ tests were performed to analyze data to compare means between the control and experimental groups. One-way ANOVA multiple-comparison tests with post hoc $t$ tests were performed for analyzing data presented in Figures $6 B$ and 9; $p$ values $<0.05$ were considered significant.

\section{Results}

\section{Selective expression of IL-10 in mouse} taste buds

To investigate the expression of IL-10 in taste tissues, we first analyzed the level of IL-10 mRNA in circumvallate and foliate epithelium from C57BL/6 mice by qRTPCR and compared this level with that in lingual epithelium devoid of taste buds. As shown in Figure $1 A$, the $I L-10$ mRNA level in taste epithelium was significantly higher than that in nontaste lingual epithelium $(p=0.001)$. In situ hybridization with antisense probes to $I L-10$ showed strong signals in taste buds (Fig. $1 B$ ), whereas sense probes showed no specific hybridization (Fig. 1C). These results demonstrate the preferential expression of IL-10 mRNA in taste buds compared with nontaste lingual epithelium. To further investigate the expression of IL-10 in taste tissues, we used an
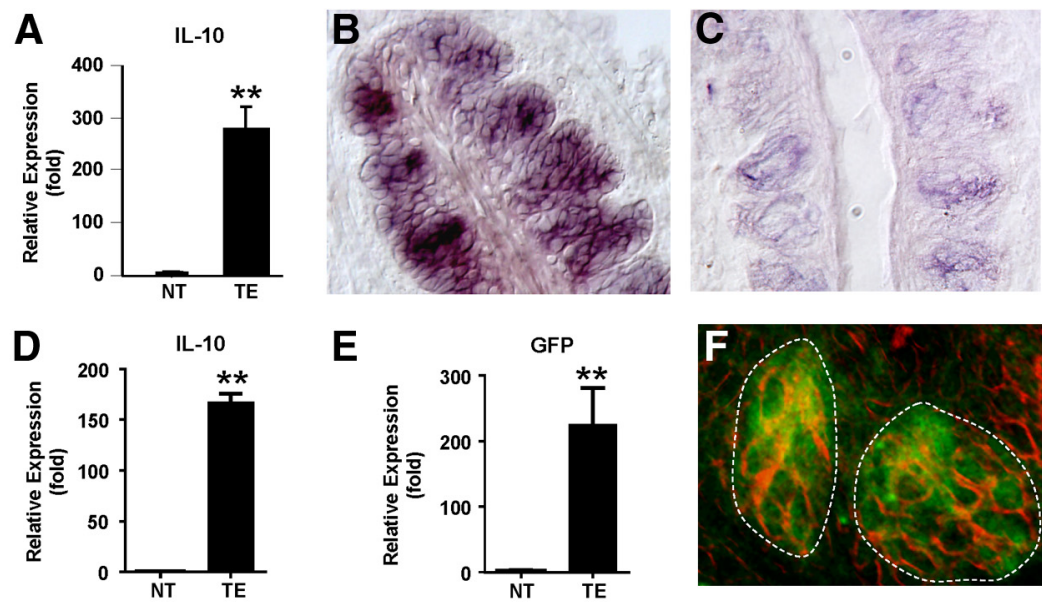

\section{E}
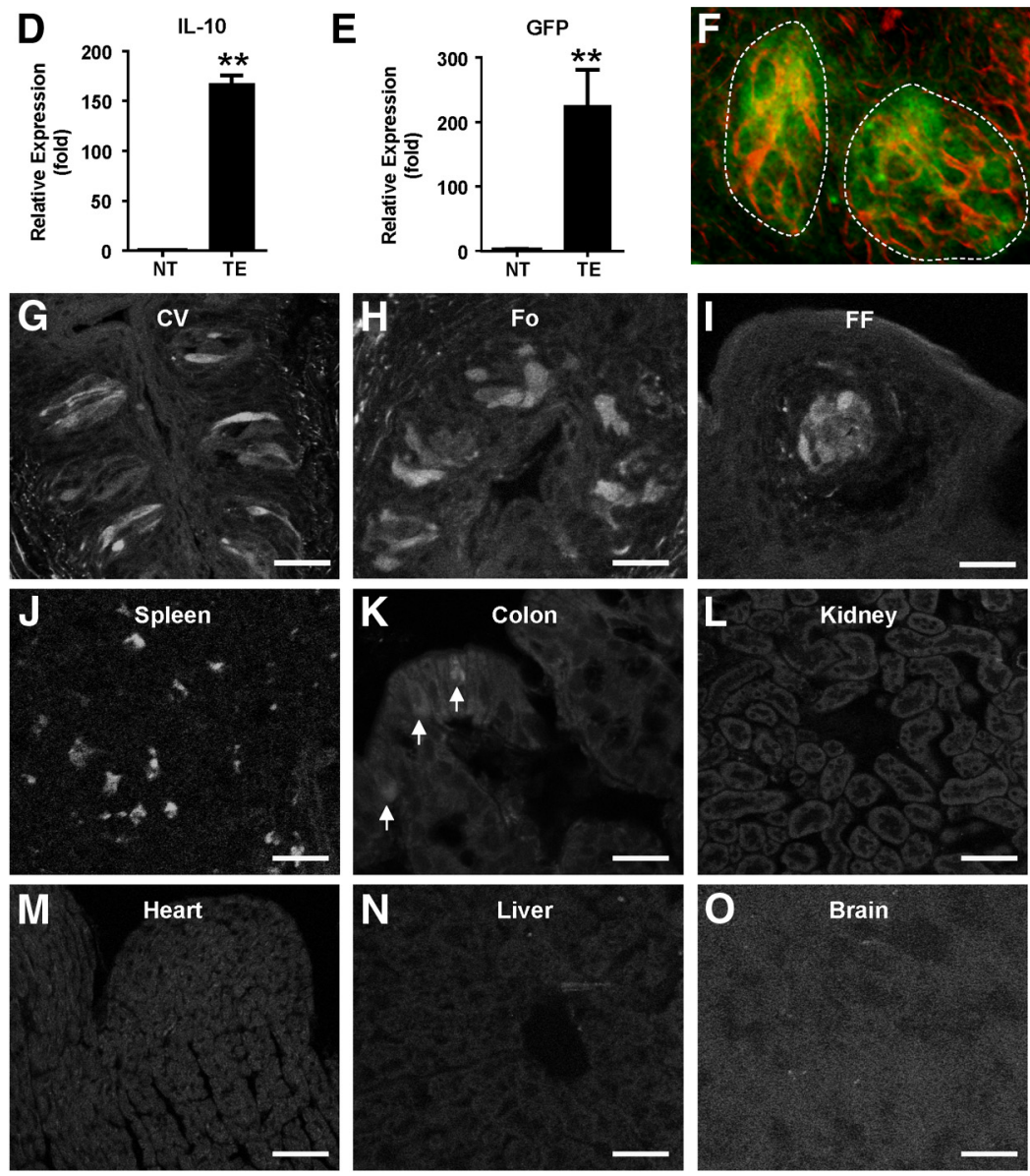

Figure 1. Expression of IL-10 in the taste buds and other tissues. A, qRT-PCR analysis of IL-10 expression in taste (TE) and nontaste (NT) lingual epithelia of C57BL/6 mice: relative expression levels (fold) of IL-10 mRNA. $\beta$-Actin served as an endogenous control gene for relative quantification, and IL-10 expression level in nontaste samples was designated as 1. Taste and nontaste epithelial tissues from three mice were pooled for each set of RNA sample preparations. Data are mean $\pm S D ;{ }^{* *} p=0.001$ (unpaired two-tailed $t$ test, $\mathrm{df}=4, n=3$ experiments). $B, C$, IL-10 mRNA in situ hybridization. Mouse circumvallate sections were processed for in situ hybridization with antisense $(\boldsymbol{B})$ and sense $(\boldsymbol{C})$ probes to mouse IL-10. D, E, qRT-PCR analysis of IL-10 and GFP mRNA expression in IL-10-GFP mice. Relative expression levels (fold) in taste (TE) and nontaste (NT) lingual epithelia were analyzed using $\beta$-actin as the endogenous control gene. Expression levels in nontaste samples were designated as 1 . Data are mean $\pm S D ;{ }^{* *} p=0.0002$ in $\boldsymbol{D} ;{ }^{* *} p=0.001$ in $\boldsymbol{E}$ (unpaired two-tailed $t$ test, $\mathrm{df}=4, n=3$ experiments). $\boldsymbol{F}$, Colocalization of GFP fluorescent signal (green) with $I L-10$ antisense probe in situ hybridization (pseudocolored red) on a circumvallate section from IL-10-GFP mice. Two taste buds are shown (circled areas). G-0, IL-10 expression was detected by intrinsic fluorescence of GFP (white) in IL-10-GFP mice in taste papillae $(\mathbf{G}-\boldsymbol{I})$ and other tissues $(\boldsymbol{J}-\mathbf{0})$. Strong GFP signals were observed in circumvallate papillae $(\mathrm{CV} ; \boldsymbol{G})$, foliate papillae $\left(\mathrm{F}_{0} ; \boldsymbol{H}\right)$, and fungiform papillae (FF; $I)$, as well as in the spleen, an immune organ $(J)$, which was used as a positive control. Weak but detectable levels of GFP signals were also observed in some cells of the colon epithelium ( $\boldsymbol{K}$, arrows). No GFP expression was observed in the kidney $(\boldsymbol{L})$, heart $(\boldsymbol{M})$, liver $(\boldsymbol{N})$, or brain (0). Scale bars: $\mathbf{G}-\boldsymbol{K}, 20 \mu \mathrm{m} ; \boldsymbol{L}-\mathbf{0}, 40 \mu \mathrm{m}$.

IL-10 reporter mouse line that carries a knock-in IRES-GFP following the $I L-10$ coding region (IL-10-GFP mice; Kamanaka et al., 2006). The expression of GFP was shown to correlate with the expression of IL-10 in various immune cells from these mice (Kamanaka et al., 2006). To confirm that GFP expression also reflects IL-10 expression in taste tissues, we analyzed the expression of IL-10 and GFP mRNA in taste versus nontaste lingual 

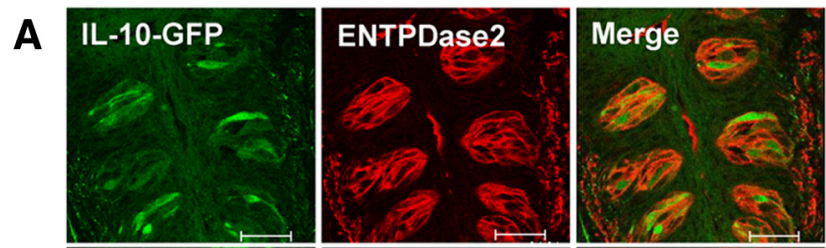

B
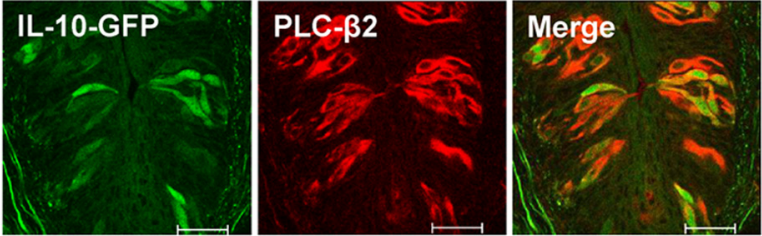

C
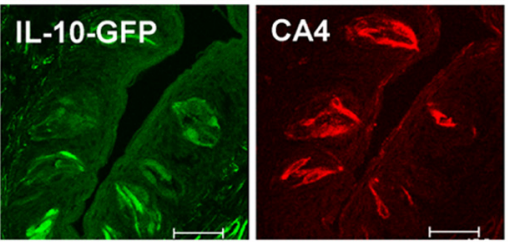

D
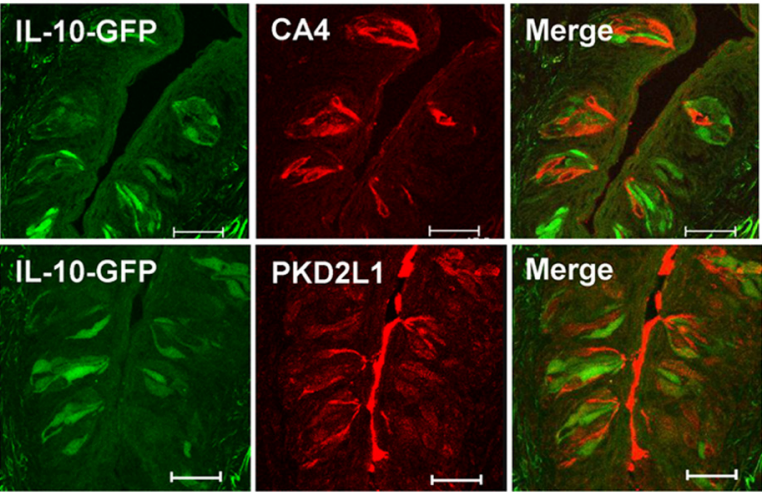

Figure 2. Identification of IL-10-producing cells in taste buds. Confocal images of intrinsic fluorescence of GFP (green) and immunofluorescent staining of different taste cell-type markers (red) on circumvallate papillae sections from IL-10-GFP mice. $A$, Immunostaining of type I taste cell marker ENTPDase2 (red), showing no GFP expression in type I taste cells. $\boldsymbol{B}$, Immunostaining of type II taste cell marker PLC- $\beta 2$ (red), showing GFP expression in type II taste cells. Note that all GFP-positive cells express PLC- $\beta 2$, but some PLC $\beta 2$-positive cells do not express IL-10. C, D, Immunostaining of type III taste cell markers CA4 (red) and PKD2L1 (red) showing no GFP expression in type III taste cells. Five mice were included in each experimental group. Scale bars: $30 \mu \mathrm{m}$.

epithelia from IL-10-GFP mice by qRT-PCR. As shown in Figure 1, $D$ and $E$, both IL-10 and GFP showed preferential expression in the taste epithelium ( $p=0.0002$ for IL-10, $p=0.001$ for GFP), similar to IL-10 expression in C57BL/6 mice (Fig. 1A). In addition, in situ hybridization using antisense probes to IL-10 showed colocalization of IL-10 hybridization signals with GFP fluorescence in taste bud cells of IL-10-GFP mice (Fig. $1 F$ ), suggesting that GFP expression correlates with IL-10 expression in taste buds of these reporter mice. Further analyses of IL-10-GFP mice showed that GFP signal was evident in taste buds of all three types of taste papillae on the tongue, with GFP-expressing cells displaying typical slender morphology of taste cells within taste buds (Fig. 1G-I). Taste papillae and taste buds from these mice exhibit normal morphology. Because some splenic leukocytes from naive mice were reported to express IL-10 (Madan et al., 2009), we also examined tissue sections from the spleen as a positive control. As expected, numerous GFP-positive cells were observed in the spleen (Fig. $1 J$ ). To ascertain the tissue specificity of IL-10 expression, we further examined the presence of GFP-positive cells in colon, kidney, heart, liver, and brain (Fig. $1 K-O$ ). Some GFPpositive cells were observed in colon epithelium (Fig. $1 K$ ); no obvious expression of GFP was detected in the other tissues.

The results suggest that the taste bud, a highly specialized structure in the oral cavity, can produce the cytokine IL-10 in addition to its basic functions in taste signaling. These results also indicate that IL-10 in taste buds is produced by taste cells themselves and not by infiltrating leukocytes, because our previous

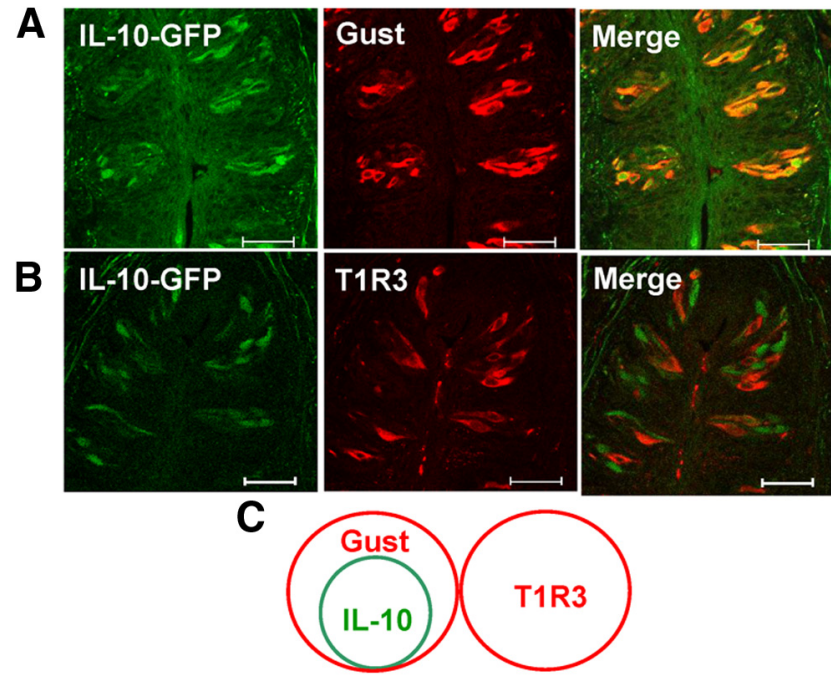

Figure 3. Identification of a subpopulation of type II taste cells that express IL-10 in mouse taste buds. Confocal images of intrinsic fluorescence of GFP (green) and immunofluorescent staining of different type II taste cell markers (red) on circumvallate papillae sections from IL-10-GFP mice. $\boldsymbol{A}$, Immunostaining of gustducin (Gust; red), showing GFP is coexpressed with gustducin in type II taste cells. $\boldsymbol{B}$, Immunostaining of T1R3 (red), showing no coexpression of GFP and T1R3 in taste cells. Scale bars: $35 \mu \mathrm{m}$. C, Venn diagrams illustrate colocalization of IL-10 (represented by GFP signals) with gustducin (Gust), but not with T1R3 in circumvallate sections of IL-10-GFP mice.

studies found no infiltration of immune cells in taste buds of healthy subjects (Feng et al., 2009, 2010, 2012).

\section{Selective expression of IL-10 in type II taste cells}

Taste buds contain three types of mature taste cells: type I cells that may function as supporting cells; type II cells that are responsible for sweet, bitter, and umami taste reception; and type III cells that may detect salty and sour taste compounds (Finger, 2005; Chaudhari and Roper, 2010). Each of these three types of taste cells can be identified by different biomarkers that are expressed specifically by these cell types. To study what types of taste cells produce IL-10, we performed immuno-colocalization experiments using IL-10-GFP mice and antibodies specific to various taste cell-type markers. As shown in Figure 2, GFP was exclusively expressed in type II taste cells labeled by an antibody to PLC- $\beta 2$ (Fig. $2 B$ ) and was not detected in type I cells labeled by an antibody to ENTPDase2 (Fig. $2 A$ ) or type III cells labeled by antibodies to CA4 and PKD2L1 (Fig. 2C,D). The results indicate that type II taste cells are the exclusive cellular source for IL-10 produced in taste buds. It is also noteworthy that almost all IL10 -producing cells in taste buds are PLC- $\beta 2$ positive, whereas less than half of PLC- $\beta 2$-positive cells in taste buds of circumvallate papillae express IL-10 (Fig. $2 B$ ). These observations suggest that PLC- $\beta 2$-expressing type II taste cells are heterogeneous in terms of IL-10 expression.

\section{IL-10 is selectively produced by gustducin-expressing type II taste cells}

Different from type I and III taste cells, type II cells express G-protein-coupled T1R and T2R taste receptors and their downstream signaling molecules, such as PLC- $\beta 2$, TrpM5, and gustducin (a G-protein $\alpha$-subunit; McLaughlin et al., 1992; Huang et al., 1999; Pérez et al., 2002; Zhang et al., 2003). However, type II cells are heterogeneous in function and in expression of taste receptors: umami, sweet, and bitter type II cells express umami (T1R1/T1R3), sweet (T1R2/T1R3), and bitter (T2Rs) receptor 
molecules, respectively (Hoon et al., 1999; Adler et al., 2000; Matsunami et al., 2000; Max et al., 2001). The expression of G-protein subunits, such as gustducin, is also heterogeneous among type II cells. Gustducin and T1R3, a critical subunit of umami and sweet taste receptors, are coexpressed in fungiform taste buds but are mostly segregated in circumvallate taste buds (Kim et al., 2003; Feng et al., 2012; Tomonari et al., 2012). Most gustducinexpressing cells in circumvallates are bitter receptor cells (Adler et al., 2000; Kim et al., 2003). To further investigate the subpopulation of type II taste cells that produce IL-10, we analyzed the coexpression of GFP with T1R3 and gustducin in circumvallate and foliate papillae from IL-10-GFP mice. As shown in Figure 3, most, if not all, GFP-positive cells in circumvallate taste buds are also positive for gustducin (Fig. $3 A, C$ ), whereas GFP expression is not detected in T1R3-positive sweet and umami receptor cells (Fig. $3 B, C$ ), suggesting that IL-10-producing cells are mostly bitter receptor cells in circumvallate taste buds. Same colocalization patterns were also observed in foliate taste buds (data not shown). These data strongly suggest that gustducin-expressing type II bitter receptor cells are the exclusive cellular source of IL-10 in posterior taste buds.

\section{IL-10 and TNF- $\alpha$ are produced by distinct subtypes of type II taste cells}

Our recent research demonstrated that the cytokine TNF- $\alpha$ was also produced by a subset of type II taste cells identified by PLC- $\beta 2$ and the taste receptor T1R3 (Feng et al., 2012). IL-10 and TNF are two important cytokines that often perform opposite biological roles in immune responses. Both are produced by many different types of cells in response to various inflammatory stimulations, although the amount of these cytokines produced depends on the type of stimuli and the cellular source (Beutler and Cerami, 1989; Saraiva and O'Garra, 2010). To address whether IL-10 and TNF are produced by the same or different type II taste cells in taste buds, we performed immunocolocalization experiments with IL-10-GFP mice using antibody against TNF and compared the expression patterns of these two cytokines in taste tissues and in the spleen. As shown in Figure 4, $A$ and $B$, IL-10 and TNF are clearly produced by different taste cells in circumvallate and foliate taste buds, and no coexpression of these two cytokines was observed. In contrast, IL-10 and TNF are highly coexpressed in the spleen, with a small fraction of cells expressing only IL-10 or TNF (Fig. 4C). These results demonstrate that although both IL-10 and TNF are expressed in taste buds by type II taste cells, they are produced by completely different subtypes of taste cells, an expression pattern that differs sharply from that in the spleen, an immune organ.

\section{SEA stimulates IL-10 expression in taste buds}

After determining the identity of IL-10-producing taste cells, we examined whether these cells can increase IL-10 expression in response to immune stimulatory agents such as SEA, which can induce IL-10 production by immune cells. We first injected IL10-GFP mice intraperitoneally with SEA, a superantigen that activates T-cells and other immune cells (Sundstedt et al., 1997; Kissner et al., 2011). Repeated administration of SEA to IL-10GFP mice has been reported to stimulate lymphocytes to produce IL-10 in the spleen and the gut (Kamanaka et al., 2006). Following the same procedure of SEA administration, we studied IL-10 expression in taste buds of IL-10-GFP mice after SEA administration. qRT-PCR analyses showed that mRNA expression of IL10 , as well as GFP, was significantly induced by SEA in taste epithelia containing circumvallate and foliate taste buds $(p=$
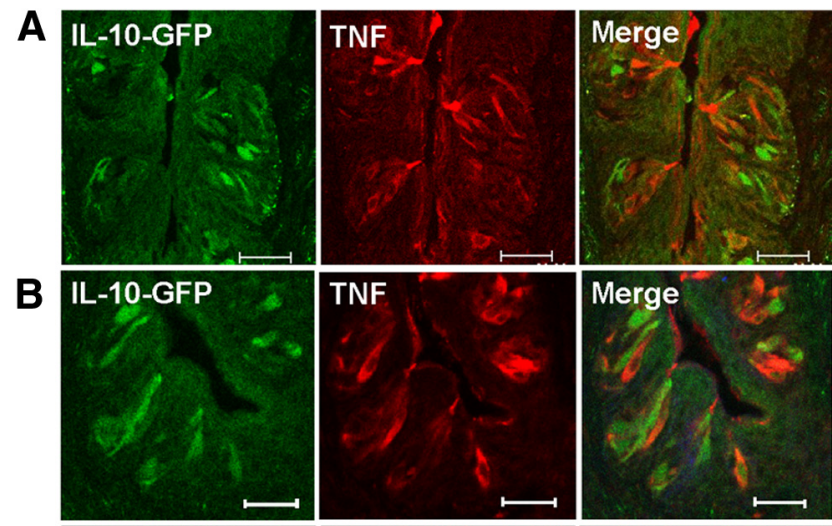

C
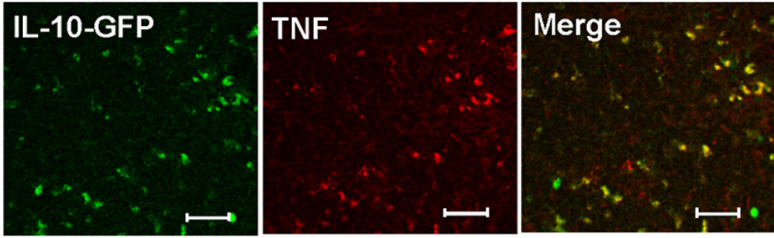

Figure 4. IL-10 and TNF are produced by different subsets of type II taste cells. Confocal images of intrinsic fluorescence of GFP (green) and immunofluorescent staining of TNF (red) on tissue sections of taste papillae $(\boldsymbol{A}, \boldsymbol{B})$ and spleen $(\boldsymbol{C})$ of IL-10-GFP mice. Both TNF and IL-10 (represented by GFP expression) were highly expressed in circumvallate $(\boldsymbol{A})$ and foliate papillae $(\boldsymbol{B})$, but no clear coexpression of IL-10 and TNF was observed, indicating separate cellular origins of these two cytokines in the taste bud. In contrast to taste tissues, most GFP-positive cells in the spleen coexpressed TNF $(C$, and only a small proportion of cells in the spleen expressed either IL-10 or TNF. Scale bars: $A, B, 25 \mu \mathrm{m} ; C, 40 \mu \mathrm{m}$.

0.002 for IL-10, $p=0.007$ for GFP; Fig. $5 A, B)$. The level of GFP fluorescence was also markedly upregulated in the taste buds of mice injected with SEA compared with PBS (vehicle control)injected control animals (Fig. 5C,D). Quantitative measurement of GFP fluorescence intensity showed a significant increase of gray values in taste buds of SEA-injected mice compared with control mice (125 vs $85, p=0.029$; Fig. $5 G$ ). In addition, the number of GFP-expressing cells in taste buds was increased in mice injected with SEA. The fraction of GFP-expressing cells among gustducin-positive cells in taste buds increased from 49 to $63 \%$ (Fig. $5 E, F$ ). As expected, serum levels of IL-10 were also significantly increased in SEA-injected mice $(p=0.041$; Fig. $5 H)$, which reflects the systemic response of the immune system to SEA stimulation. These results indicate that IL-10-expressing cells in taste buds, similar to immune cells, can be activated to increase IL-10 expression by repeated administration of SEA.

\section{LPS induces IL-10 expression and secretion in the taste epithelium}

As a gram-negative bacterial cell-wall component, LPS induces cytokine production in immune cells through Toll-like receptor (TLR)-dependent pathways (Akira et al., 2006). Binding of LPS to its cognate transmembrane receptors CD14 and TLR4 leads to activation of NF- $\kappa \mathrm{B}$ and production of cytokines, including IL10. To investigate the role of this important IL-10 induction pathway in taste cells, we injected IL-10-GFP mice with LPS (5 mg $\mathrm{kg}^{-1}$ body weight; Cohn et al., 2010) or PBS as a control and assessed levels of $I L-10$ and GFP mRNA in taste tissues $3 \mathrm{~h}$ later by qRT-PCR. As shown in Figure 6A, LPS challenge significantly increased $I L-10$ and GFP mRNA levels in taste epithelia compared with PBS control mice ( $p=0.004$ for IL-10, $p=0.0002$ for GFP). To further investigate whether taste cells can produce and secrete IL-10 into their environment, we analyzed IL-10 secretion 

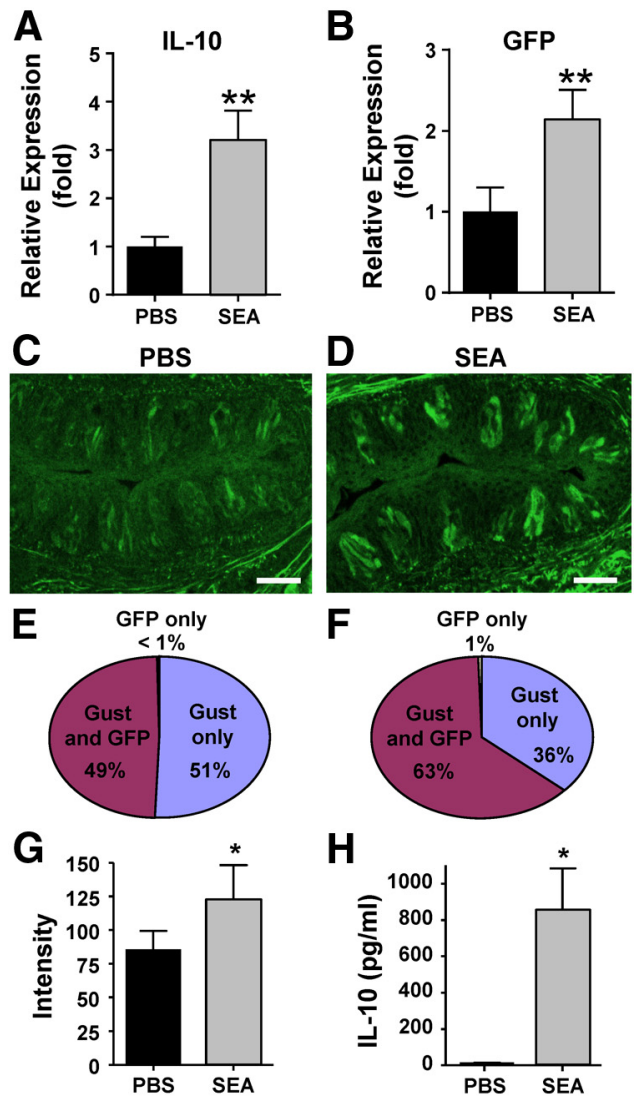

$\mathbf{F}$

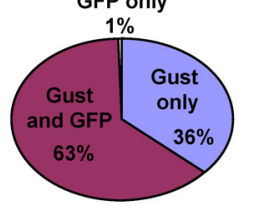

H

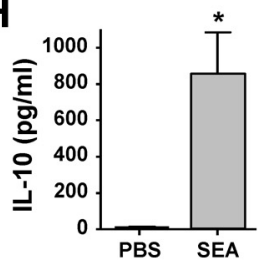

Figure 5. Increased expression of IL-10 following repeated administration of SEA. IL-10-GFP mice were injected with SEA or PBS three times with $2 \mathrm{~d}$ intervals. IL-10 and GFP mRNA expression in taste tissues was determined by qRT-PCR. GFP fluorescence in circumvallate papillae was detected using confocal microscopy. The amount of IL-10 in the blood was measured by ELISA. $A, B$, qRT-PCR analysis of IL-10 and GFP mRNA expression in taste epithelium containing circumvallate and foliate taste buds from IL-10-GFP mice injected with SEA or PBS. $\beta$-Actin served as the endogenous control gene for relative quantification. Data are mean $\pm S D ;{ }^{* *} p=0.002$ in $\boldsymbol{A}$; ${ }^{* *} p=0.007$ in $\boldsymbol{B}$ (unpaired two-tailed $t$ test, $\mathrm{df}=4, n=3$ experiments). $\boldsymbol{C}, \boldsymbol{D}$, GFP expression in circumvallate taste buds of PBS-injected control mice $(\boldsymbol{C})$ and SEA-injected mice (D) detected by intrinsic fluorescence of GFP (green). Scale bars: $40 \mu \mathrm{m} . \boldsymbol{E}, \boldsymbol{F}$, Changes in GFPand gustducin-positive (Gust) cell counts in circumvallate taste buds of IL-10-GFP mice after PBS $(\boldsymbol{E})$ or SEA $(\boldsymbol{F})$ injections, expressed as the percentage of each cell type. $\boldsymbol{G}$, Average intensities of intrinsic fluorescence of GFP of circumvallate taste buds from SEA- or PBS-treated mice. ${ }^{*} p=$ 0.029 (unpaired two-tailed $t$ test, $\mathrm{df}=5, n=3-4$ animals per group). $\boldsymbol{H}$, Concentrations of $\mathrm{IL}-10$ in the serum of PBS- and SEA-injected mice. Data are mean $\pm S D ;{ }^{*} p=0.041$ (unpaired two-tailed $t$ test, $\mathrm{df}=5, n=3-4$ animals per group).

from cultured taste tissues. Isolated foliate and circumvallate epithelia from C57BL/6 mice, as well as the tongue epithelium devoid of taste buds, were cultured in a medium with or without 5 $\mu \mathrm{g} \mathrm{ml}^{-1}$ LPS for 24-48 h (Frost et al., 2002). The amount of IL-10 in culture supernatants collected at different time points was measured by ELISA. As shown in Figure 6B, the supernatant of cultured taste epithelium treated with LPS had a low but sustained level of IL-10 over the observed time period. The amount of IL-10 was below the detection limit in cultured taste epithelium without LPS treatment or cultured nontaste epithelium with or without LPS treatment ( $p=0.04$, taste epithelia treated with LPS vs nontaste epithelia treated with LPS). These results demonstrate that taste cells can produce and secrete IL-10 in response to the inflammatory activator LPS.

T1R3-expressing cells are major targets of IL-10 in taste buds As a pleiotropic cytokine with important immunoregulatory functions, IL-10 regulates activities of many cell types in the im-
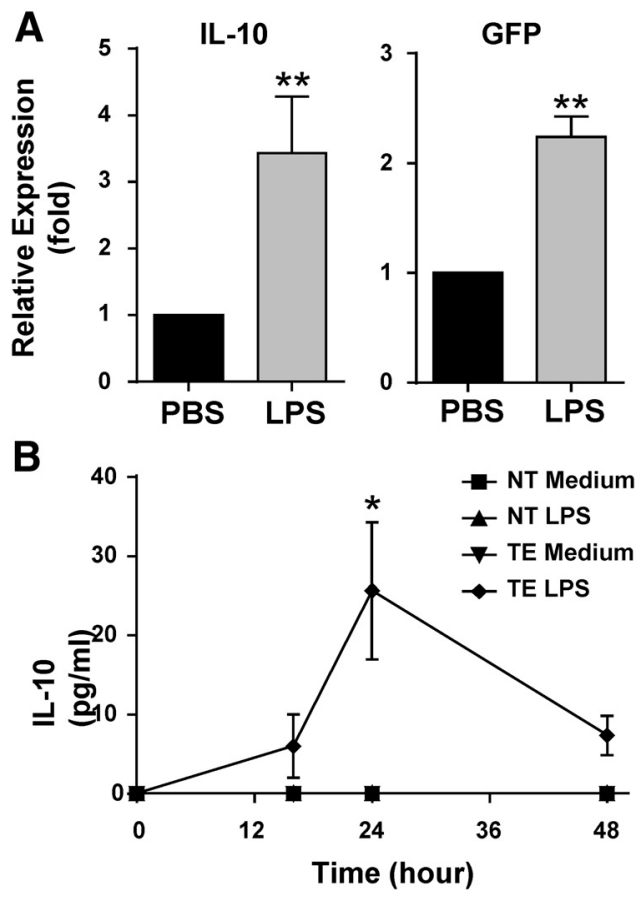

Figure 6. LPS induces IL-10 expression and secretion in taste buds. $A$, Relative levels (fold) of IL-10 and GFP mRNA expression in taste epithelia of IL-10-GFP mice. LPS or PBS (vehicle control) was intraperitoneally injected into IL-10-GFP mice, and $3 \mathrm{~h}$ later IL-10 and GFP mRNA levels in taste epithelia containing circumvallate and foliate taste buds were determined using qRT-PCR. The expression level of mRNA in taste epithelia of PBS-injected mice was defined as 1. $\beta$-Actin served as the endogenous control gene for relative quantification. Data are mean $\pm S D ;{ }^{* *} p=$ 0.004 for IL-10; ${ }^{* *} p=0.0002$ for GFP (unpaired two-tailed $t$ test, $\mathrm{df}=4, n=3$ experiments). $B$, Production and secretion of IL-10 by taste epithelia upon LPS challenge in vitro. Taste epithelia (TE; containing circumvallate and foliate taste buds) and nontaste lingual epithelia (NT) were isolated from C57BL/6 mice and incubated in complete DMEM, with or without $5 \mu \mathrm{g} \mathrm{ml}^{-1} \mathrm{LPS}$, for the time periods indicated. Cultures with no LPS in the medium served as controls. Concentrations of IL-10 in the supernatant of the cultured tissues were measured using ELISA. IL-10 was detected in the supernatant of cultured taste epithelium treated with LPS, but was below the detection limit in all other samples. Three mice were used for each treatment, and all the collected samples were assayed in duplicate for each experiment. The results are representative of three experiments. Data are mean \pm SD; ${ }^{*}$ one-way ANOVA: $F=6.88, p=0.018$; post hoc $t$ test: $p=0.04$ (TE LPS vs NT LPS).

mune system through binding to its receptor IL-10R. To identify the target cells of IL-10 in taste buds, we performed immunocolocalization experiments using antibodies against IL-10R1, the ligand-binding subunit of IL-10R, and various taste cell-type markers. As shown in Figure 7A, IL-10R1 immunoreactivities were detected in a subset of circumvallate taste bud cells (mid$\mathrm{dle}$ ), whereas no specific signals were observed when the primary antibody was omitted (left) or when the antibody was preincubated with the antigenic peptide (right). In colocalization experiments, IL-10R1 was preferentially coexpressed with type II taste cells markers PLC- $\beta 2$ and T1R3 in foliate taste buds (Fig. $7 B, D$ ), but rarely coexpressed with gustducin (Fig. 7C). IL-10R1 immunostaining was not observed in type III cells labeled by CA4 (Fig. 7E). Same colocalization patterns were also observed in circumvallate taste buds (data not shown). The results suggest that T1R3-expressing type II taste cells are the main targets of IL-10 in taste buds. To study the expression of IL-10R in the IL-10producing taste cells, we performed IL-10R1 immunostaining on taste tissue sections from IL-10-GFP mice. As shown in Figure 7F, no clear IL-10R1 expression was detected in GFP-positive taste cells. We also examined the expression of IL-10R2, the receptor 


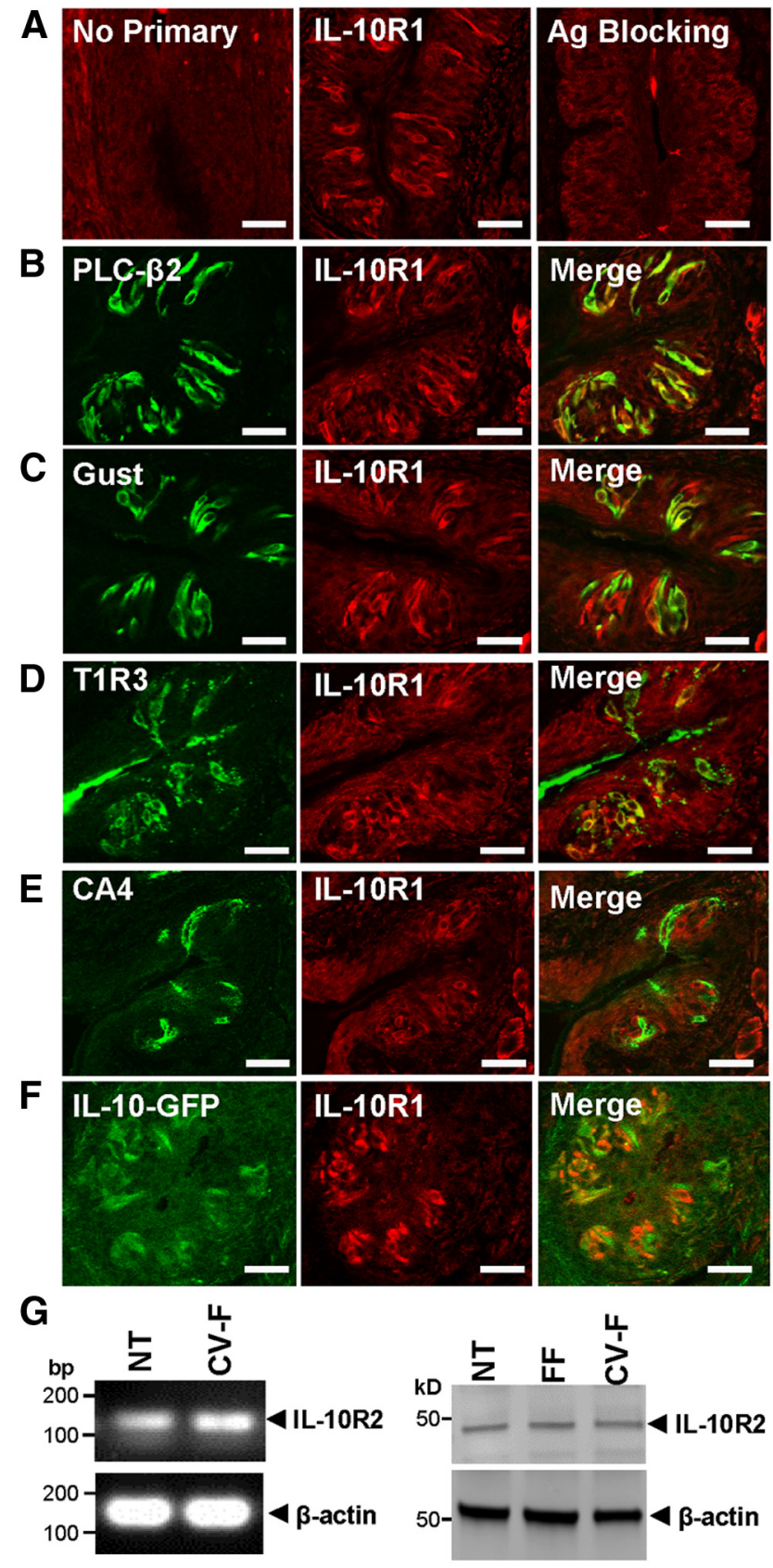

Figure 7. Identification of IL-10R1-expressing cells in taste buds. $\boldsymbol{A}$, Confocal fluorescent images of circumvallate sections stained with no specific primary antibody (No Primary), affinity-purified rabbit antibody against IL-10R1 (IL-10R1), or antibody against IL-10R1 preincubated with the peptide used for antibody production (Ag Blocking). A DyLight 649conjugated donkey anti-rabbit secondary antibody was used for the experiment. Specific staining of taste bud cells was seen only in IL-10R1 antibody staining (middle). $\boldsymbol{B}-\boldsymbol{E}$, Confocal images of double immunofluorescent staining of IL-10R1 (red) with different taste cell-type markers (green) on foliate papillae sections of C57BL/6 mice. $\boldsymbol{B}$, Immunostaining of IL-10R1 (red) and type II taste cell marker PLC- $\beta 2$ (green), showing IL-10R1 expression in type II taste cells. C, D, Immunostaining of IL-10R1 (red) and taste cell marker gustducin (Gust) or T1R3 (green), showing more selective IL-10R1 expression in T1R3-positive type II taste cells. E, Immunostaining of IL-10R1 (red) and type III taste cell marker CA4 (green), showing no IL-10R1 expression in type III taste cells. $\boldsymbol{F}$, Confocal images of intrinsic fluorescence of GFP (green) and immunofluorescent staining of IL-10R1 (red) in IL-10-GFP mice, showing largely nonoverlapping expression of IL-10R1 and GFP in foliate taste buds. G, IL-10R2 expression in taste and nontaste lingual epithelia. Left, DNA products from RT-PCR experiments showing RNA expression of IL-10R2 and $\beta$-actin in nontaste lingual epithelium (NT) and in taste epithelia containing circumvallate and foliate taste buds (CV-F). Right, Western blots using antibodies against IL$10 \mathrm{R} 2$ and $\beta$-actin showing protein expression of IL-10R2 and $\beta$-actin in nontaste
A
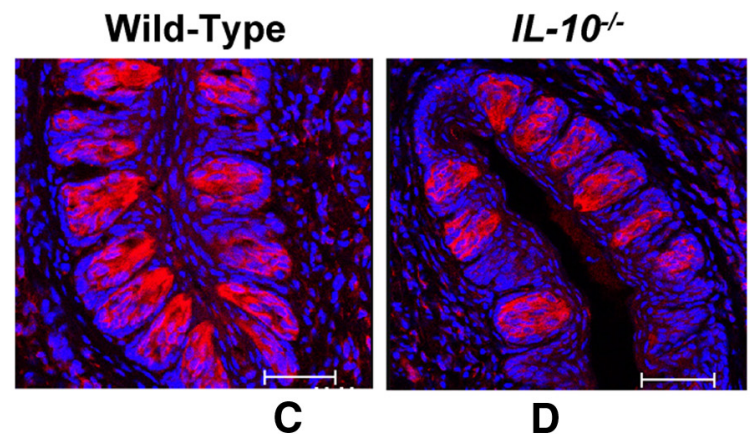

\section{B}

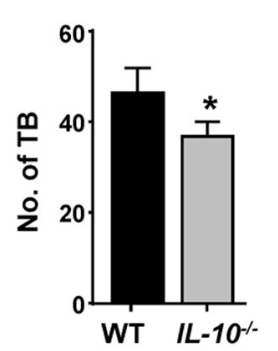

E

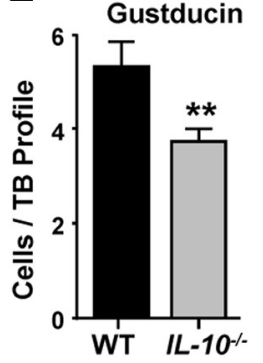

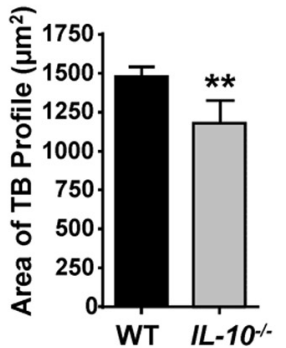

$\mathbf{F}$

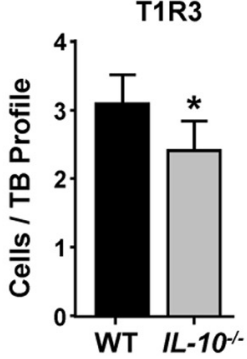

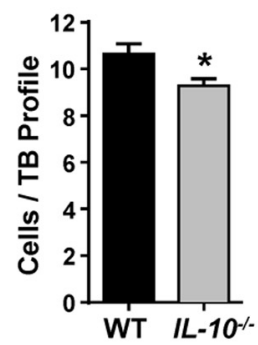

G

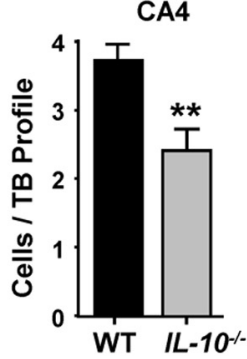

Figure 8. Structural defects in taste buds of $I L-10-k n o c k-o u t ~ m i c e . ~ A-C$, Reduction in the number and size of taste buds in $/ L-10$-knock-out $\left(I L-10^{-/-}\right)$mice compared with wild-type mice. A, Immunofluorescent staining of KCNQ1 (red) showing taste buds in typical circumvallate sections from wild-type and $/ L-10^{-I-}$ mice. DAPI staining (blue) shows nuclei. Scale bars: 100 $\mu \mathrm{m} . \boldsymbol{B}$, The number of circumvallate taste buds (TB) in $/ L-10^{-1-}$ mice was significantly reduced compared with that in wild-type (WT) control mice; ${ }^{*} p=0.034$ (df $=7, N=4-5$ animals per group). $C$, The average area of TB profiles from $I L-10^{-1-}$ mice was significantly decreased; ${ }^{* *} p=0.0038$ ( $\mathrm{df}=7, N=4-5$ animals per group). $\boldsymbol{D}$, The average number of taste cells per taste bud profile was significantly reduced in $/ L-10^{-I-}$ mice; ${ }^{*} p=0.0241(\mathrm{df}=$ $9, n=5-6$ animals). $\boldsymbol{E}-\boldsymbol{G}$. Decreased numbers of type II (gustducin labeled or T1R3 labeled) and type III (CA4 labeled) taste receptor cells in $I L-10^{-I-}$ mice compared with those in WT control mice. The circumvallate taste tissues were immunostained with antibodies to gustducin, T1R3, and CA4, and the numbers of specifically stained cells in each taste bud with typical morphology were counted and averaged. At least five taste buds were selected from each section; ${ }^{* *} p=0.001\left(\boldsymbol{E}\right.$, the number of gustducin-expressing cells); ${ }^{*} p=0.047(\boldsymbol{F}$, the number of T1R3-expressing taste cells); ${ }^{* *} p=0.002$ ( $G$, the number of CA4-expressing taste cells). Data were analyzed using unpaired two-tailed $t$ test; $\mathrm{df}=7, N=4-5$ animals per group. Data are mean \pm SD.

signaling subunit shared by IL-10, IL-22, IL-26, and IL-28 (Donnelly et al., 2004). RT-PCR and Western blotting experiments showed that IL-10R2 is expressed in taste, as well as nontaste lingual epithelia (Fig. 7G). This result is consistent with previous reports that showed broader tissue distribution of IL-10R2 compared with IL-10R1 (Donnelly et al., 2004). Together, these observations suggest that IL-10 produced by taste cells targets

lingual epithelium (NT), in taste epithelium containing fungiform taste buds (FF), and in taste epithelia containing circumvallate and foliate taste buds (CV-F). Five mice per group were included in the immunostaining experiments. Scale bars: $30 \mu \mathrm{m}$. 
A
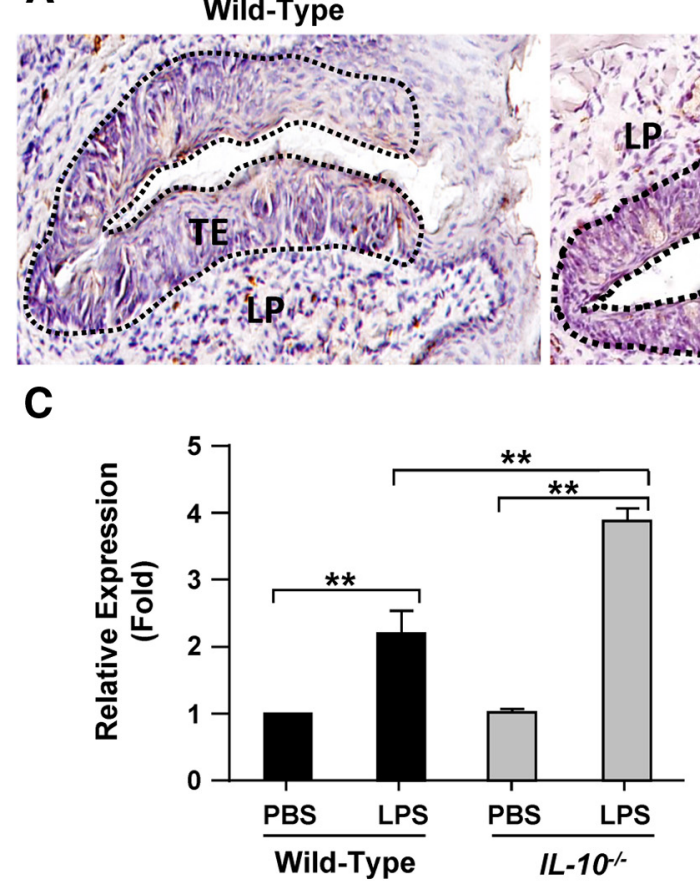

B

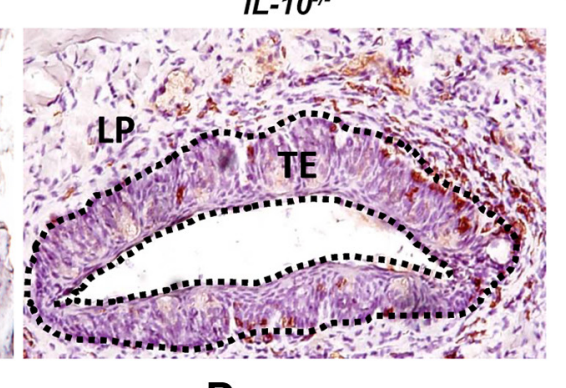

D

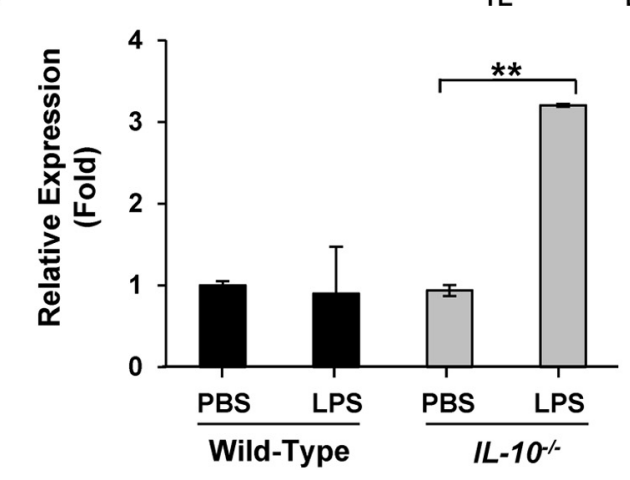

Figure 9. T-cell infiltration and TNF responses in taste tissues of $I L-10$-knock-out mice. $A, C D 3^{+}$T-cells in the taste epithelium (TE) and lamina propria (LP) of circumvallate papillae from wild-type and $/ L-10-$ knock-out $\left(I L-10^{-I-}\right.$ ) mice. T-cells were labeled by an anti-CD3 antibody (brown). B, Quantitative analysis of T-cell populations in the TE and LP of wild-type (WT) and $I L-10^{-1-}$ mice. T-cell populations in TE and LP were significantly increased in $I L-10^{-1-}$ mice compared with WT mice. Data are mean $\pm S D$; **one-way ANOVA multiple-

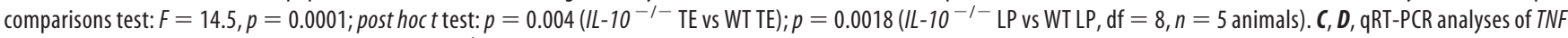
mRNA expression in taste epithelia of WT and $/ L-10^{-1-}$ mice after LPS stimulation. LPS ( $0.5 \mathrm{mg} / \mathrm{kg}$ body weight) or PBS (vehicle control) was injected intraperitoneally into WT and $I L-10^{-I-}$ mice, and circumvallate- and foliate-containing taste epithelia were collected $16 \mathrm{~h}(\boldsymbol{C})$ or $5 \mathrm{~d}(\boldsymbol{D})$ later for TNF mRNA analysis. $\beta$-Actin served as the endogenous control gene for relative quantification. Data are mean $\pm S D$; ${ }^{* *}$ one-way ANOVA multiple-comparisons test: $F=148.2, p=0.0001(\boldsymbol{C}) ; F=38.36, p=0.007$ (D); post hoc $t$ test: $p=0.0035$ (C, WT

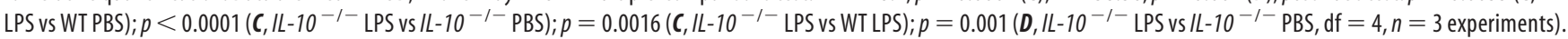

predominantly T1R3-expressing taste cells, which are TNFproducing cells in taste buds (Feng et al., 2012).

\section{IL-10 deficiency leads to reduced number of taste buds and taste receptor cells}

IL-10 is a potent immunoregulator in the gut. IL-10-knock-out $\left(I L-10^{-I-}\right)$ mice develop chronic enterocolitis with elevated inflammation in response to the intestinal microflora (Kühn et al., 1993). To study the role of IL-10 in the maintenance of the peripheral taste system, we quantified the number and size of circumvallate taste buds from $I L-10^{-1-}$ mice at $\sim 3-6$ months of age when they already showed signs of chronic enterocolitis, such as rectal prolapse, diarrhea, and weight loss (Kühn et al., 1993). Age- and sex-matched wild-type C57BL/6 mice were used as controls. $I L-10^{-1-}$ mice had been backcrossed to C57BL/6 genetic background for 13 generations. Tissue sections containing circumvallate papillae were immunostained with antibodies to KCNQ1, a marker of all taste cells (Wang et al., 2009b), to reveal the gross structure of taste buds (Fig. 8A). The number of taste buds was counted in circumvallate sections. The areas of taste bud profiles with typical morphology (i.e., those with clear taste pores and the base of taste buds reaching the basement membrane) were measured based on KCNQ1 immunostaining using a computer program (Las NF Lite image analysis software). The number and size of taste buds in circumvallate papillae of $I L-10^{-1-}$ mice were both significantly reduced compared with wild-type control mice ( $p=0.034$ for taste bud number, $p=0.0038$ for the area of taste bud profiles; Fig. $8 B, C$ ). In addition, we observed a decrease in the number of taste cells per taste bud profile in $I L-10^{-1-}$ mice based on DAPI staining and KCNQ1 immunostaining ( $p=0.0241$; Fig. $8 D$ ). These results suggest that IL- 10 is a necessary factor in the maintenance of structural integrity of taste buds and that lack of IL-10 expression leads to abnormalities of taste buds from $I L-10^{-1-}$ mice. To further investigate whether taste receptor cells are affected in these $I L-10^{-I-}$ mice, we immunostained type II and III cells using antibodies against gustducin, T1R3, and CA4. As shown in Figure 8, E-G, the numbers of cells that express type II taste cell markers gustducin and T1R3 and type III cell marker CA4 were significantly reduced in circumvallate taste buds of $I L-10^{-1-}$ mice compared with wild-type control mice $\left(p=0.001\right.$ for gustducin ${ }^{+}$cells, $p=0.047$ for $\mathrm{T} 1 \mathrm{R}^{+}{ }^{+}$cells, $p=0.002$ for $\mathrm{CA} 4^{+}$cells). These results suggest that both type II and III taste receptor cells in taste buds are affected, indicating general effects of IL-10 on growth or survival of taste cells.

\section{IL-10 deficiency leads to increased inflammatory responses in taste tissues}

To investigate the roles of IL-10 in preventing excessive inflammation, we examined leukocyte infiltration and TNF expression in taste tissues of $I L-10^{-1-}$ mice. We found that the number of $\mathrm{CD}^{+} \mathrm{T}$ lymphocytes was significantly increased in the taste epithelium $(p=0.004)$ and in the lamina propria $(p=0.0018)$ of taste papillae in $I L-10^{-1-}$ mice (Fig. $\left.9 A, B\right)$. Increased infiltration and accumulation of T-cells suggest that immune cells may contribute to the defects observed in taste tissues of $I L-10^{-I-}$ mice. Given the critical role of IL-10 in the 


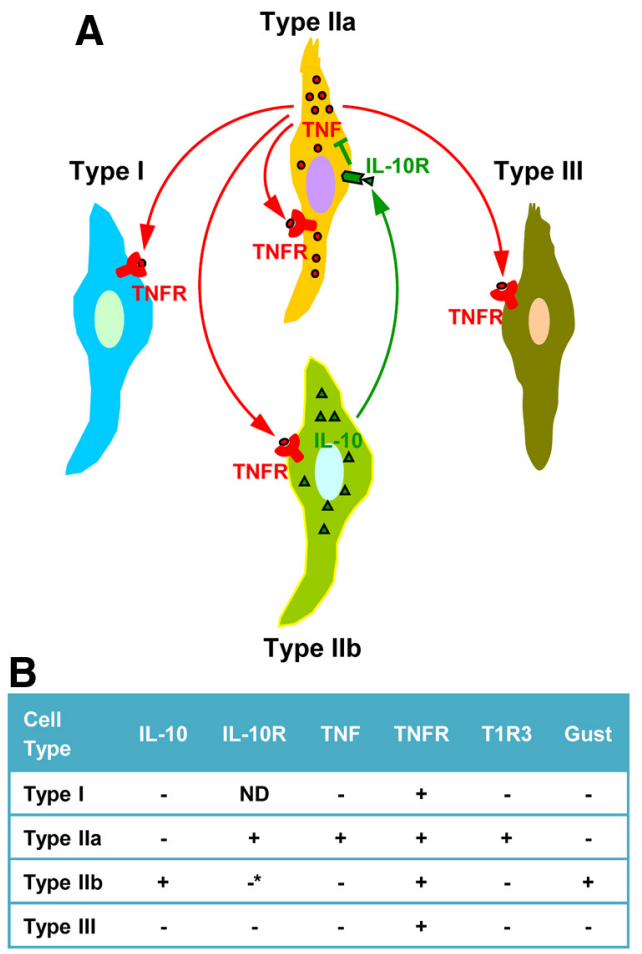

Figure 10. Proposed model of cell-cell interactions through IL-10 and TNF signaling among different types of taste cells. $A$, Circumvallate and foliate taste buds have two subsets of type II cells, based on the differential expression of TNF and IL-10, which also coincide with the differential expression of T1R3 and gustducin. The first subset (type lla) is characterized by the expression of TNF and T1R3, and the second subset (type Ilb) features the expression of IL-10 and gustducin. In addition, TNFRs are ubiquitously expressed in taste buds, and their expression has been detected in type I, Ila, IIl, and III cells. IL-10 receptor (IL-10R), however, is predominantly expressed in type lla cells. These expression patterns suggest that type lla cells (sweet and umami receptor cells) produce TNF, which can act on all taste cells via TNFR, and type llb cells (mostly bitter receptor cells) produce IL-10, which selectively acts on type lla cells to downregulate TNF production. This signaling paradigm indicates a novel mechanism of cell-cell communication in taste buds and also explains the general protective effects of IL-10 in taste buds. $\boldsymbol{B}$, Summary of expression of IL-10, IL-10R, TNF, TNFR, T1R3, and gustducin (Gust) in different types of circumvallate and foliate taste cells. + , expressed; - , no detectable expression; $-{ }^{*}$, not expressed in most of the cells; ND, not determined.

regulation of TNF expression, we further asked whether IL-10 deficiency can lead to excessive TNF expression in taste buds of $I L-10^{-I-}$ mice. We injected $I L-10^{-I-}$ and wild-type control mice with LPS (intraperitoneally) to induce systemic inflammatory responses. TNF mRNA expression was analyzed by qRT-PCR. As shown in Figure 9C, the expression level of TNF in taste epithelia of $I L-10^{-I-}$ mice was significantly enhanced compared with wild-type mice at $16 \mathrm{~h}$ post-LPS injection ( $p=$ $0.0016, I L-10^{-1-}$ LPS vs wild-type LPS). More interestingly, $5 \mathrm{~d}$ after LPS injection the enhanced expression of TNF mRNA in the taste epithelium was sustained in $I L-10^{-1-}$ mice, whereas the expression of TNF had returned to the basal level in wild-type mice (Fig. 9D). These results support that IL-10 plays important roles downregulating TNF responses in taste tissues. In Figure 10 we propose a model to illustrate how IL-10 signaling may regulate the expression and action of TNF in taste buds.

\section{Discussion}

Exposed to the oral cavity and lacking a strong physical barrier, taste buds face unique challenges in defense against pathogens and other noxious agents. Recent studies have shown that taste cells express high levels of various molecules associated with innate defense responses, including multiple inflammatory cytokines (Wang et al., 2007, 2009a; Hevezi et al., 2009; Cohn et al., 2010; Feng et al., 2012; Kim et al., 2012; Shi et al., 2012). However, too much production of inflammatory cytokines can induce cell death and inhibit cell renewal in taste buds, which may contribute to the development of taste disorders associated with various diseases (Wang et al., 2007; Cohn et al., 2010; Kim et al., 2012). Mechanisms to counter-regulate local inflammatory cytokine production would be crucial to maintaining the integrity of peripheral taste structures. In this study, using an IL-10 reporter mouse line, we were able to detect the expression of the antiinflammatory cytokine IL-10 in a specific subset of taste receptor cells, the gustducin-expressing type II cells. In addition, IL-10expressing taste cells do not overlap with TNF-expressing taste cells, at least not in circumvallate and foliate taste buds. In contrast, IL-10 receptors are preferentially expressed by TNFexpressing taste cells, which are the T1R3-expressing taste receptor cells. These results revealed a novel paracrine signaling mechanism involving IL-10 and IL-10R and two subsets of type II taste receptor cells. The expression of IL-10 can be upregulated in taste buds by immune activators such as SEA and LPS, most likely to counterbalance the upregulation of proinflammatory cytokines, such as TNF, under similar conditions (Cohn et al., 2010). Excessive and prolonged expression of TNF was observed in the taste epithelium of $I L-10^{-I-}$ mice. The function of IL-10 is important for maintaining the integrity of taste buds, because IL-10 deficiency leads to reduced number and size of taste buds and reduced number of taste receptor cells.

Because of the technical difficulties in directly detecting IL-10 in vivo, IL-10 reporter mice provide valuable tools for identifying IL-10-producing cells in various organs and tissues (Kamanaka et al., 2006; Maynard et al., 2007; Madan et al., 2009). The IL-10GFP mouse line used in this study has been used to detect IL-10 expression in intraepithelial lymphocytes in the small intestine and in colonic lamina propria lymphocytes (Kamanaka et al., 2006). It has been established that many immune cell types can produce IL-10, including innate immune cell types, such as macrophages, monocytes, dendritic cells, and neutrophils, and adaptive immune cell types, such as B-cells and various subtypes of T-cells (Saraiva and O'Garra, 2010). It has been shown that IL-10 expression in T-cells, B-cells, and myeloid cells has nonredundant roles in various disease models (Roers et al., 2004; Madan et al., 2009; Bosschaerts et al., 2011). In contrast, the expression and function of IL-10 in nonimmune cells remain less understood. In this study, we used qRT-PCR, in situ hybridization, and IL-10-GFP reporter mice to examine IL-10 expression in taste buds. In agreement with previous reports (Autschbach et al., 1998; Madan et al., 2009), IL-10 expression was detected in some spleen cells and gut epithelial cells (Fig. 1). To our surprise, GFP expression was readily detectable in a subset of taste receptor cells from IL-10-GFP mice (Fig. 1-3). It is remarkable that IL-10 production in taste buds is restricted to only a subset of gustducin-expressing taste receptor cells. In circumvallate taste buds, gustducin is mostly coexpressed with bitter taste receptors (Adler et al., 2000; Kim et al., 2003). In addition, IL-10 expression was not detected in T1R $3^{+}$cells, suggesting that, at least in posterior taste papillae, IL-10 is produced by bitter receptor cells. Whether this is also the case for taste buds in fungiform papillae and soft palate remains to be determined. In posterior taste buds, IL-10 and TNF are produced by different subsets of taste receptor cells (Fig. 4). As 
reported previously, TNF-producing cells in taste buds are $\mathrm{T} 1 \mathrm{R} 3^{+}$sweet and umami receptor cells (Feng et al., 2012). In contrast, IL-10 and TNF are frequently coproduced by various immune cells, as shown in the spleen (Fig. 4C). The mechanisms for cell type-specific expression of IL-10 and TNF in taste buds will be investigated in the future.

Immune cells can respond rapidly to proinflammatory factors, such as microbes and their toxins, and produce various cytokines. The similar feature seems also true for IL-10producing taste cells when they were stimulated with LPS or SEA. Repeated administration of SEA to IL-10-GFP mice can increase IL-10 production in the spleen and intestinal lymphocytes based on fluorescence-activated cell sorting analysis (Kamanaka et al., 2006). Following the same procedure of SEA administration, we observed in this study that IL-10 mRNA expression can be markedly induced in the taste epithelium and the intensity of GFP fluorescence, as well as the number of GFP-expressing cells, was significantly increased in taste buds of IL-10-GFP mice (Fig. 5). SEA was shown to activate T-cells and other immune cells through binding to T-cell receptors or MHC class II molecules (Kamanaka et al., 2006; Kissner et al., 2011). How SEA induces IL-10 release in taste buds remains unclear. LPS activates immune cells through TLR-mediated pathways (Akira et al., 2006). Previously, we have shown that taste bud cells express multiple TLRs, including TLR4, the receptor for LPS (Wang et al., 2009a). Consistently, LPS induces the expression and production of IL-10 both in vivo and in vitro (Fig. 6).

Autocrine and paracrine signaling plays important regulatory roles in taste buds (Huang et al., 2007; Cao et al., 2009). Various signaling molecules, such as neuropeptides and hormones, can act on taste cells, and some of them have been shown to regulate taste responses and influence peripheral taste structures (Shigemura et al., 2004; Zhao et al., 2005; Yoshida et al., 2010). Cytokines are signaling molecules that are important in the communication among cells of multicellular organisms. As a proinflammatory cytokine, TNF often induces apoptosis by binding to its receptors and activating cell death pathways (Varfolomeev and Ashkenazi, 2004). In contrast, IL-10 suppresses the expression of TNF and other proinflammatory cytokines and promotes cell growth and survival (Saraiva and O'Garra, 2010). They exert their actions via specific cell-surface receptors on their target cells through either paracrine or autocrine routes. The T1R3-expressing taste cells were found to be the major target cells of IL-10, as IL-10R1 expression was observed preferentially in these cells (Fig. 7). Considering that these cells are also TNFproducing cells, we believe this expression pattern of IL-10R1 provides an important route for IL-10-producing bitter receptor cells (defined here as type IIb cells; Fig. 10) to regulate TNF production by T1R3-expressing sweet and umami receptor cells (defined here as type IIa cells). This hypothesis is supported by the observation showing excessive and prolonged expression of TNF in $I L-10^{-1-}$ mice after LPS injection (Fig. 9). The distribution patterns of TNF receptors (TNFR) on taste cells are remarkably different from that of IL-10R in taste buds. TNFR1 and TNFR2 are globally expressed in taste buds without obvious cell-type preference (Feng et al., 2013). This may suggest a general effect of T1R3-expressing taste cells on all taste bud cells through TNF signaling. Figure 10 illustrates our proposed signaling paradigm of IL-10 and TNF in taste buds. Given the apparent antithetical actions of IL-10 and TNF in various situations and their unique expression patterns in taste buds, it is possible that IL-10 and TNF may also participate in other aspects of cell-cell communication in taste buds.
Consistent with this IL-10/TNF signaling model, IL-10 deficiency leads to structural defects in the taste tissue of 3- to 6-month-old $I L-10^{-1-}$ mice that had shown signs of chronic enterocolitis. Circumvallate taste buds from these mice are smaller and fewer in number (Fig. $8 A-C$ ), and numbers of taste receptor cells that are positive for gustducin, T1R3, or CA4 were significantly reduced (Fig. $8 E-G$ ), suggesting that IL-10 plays important roles in maintaining structural integrity of taste buds. Our previous studies have shown that excessive inflammation induced by LPS inhibits taste cell renewal and shortens taste cell life span (Cohn et al., 2010). IL-10 ${ }^{-1-}$ mice develop chronic enterocolitis in response to environmental microbes under conventional animal care conditions (Kühn et al., 1993). Taste tissues of $I L-10^{-/-}$mice exhibit increased inflammatory responses (Fig. 9). Without the inhibitory effects of IL-10, TNF may drive the expression of various inflammatory cytokines in taste tissues, which would slow down cell renewal and accelerate cell death in taste buds. Additionally, gut inflammation in $I L-10^{-1-}$ mice can interfere with nutrient absorption. The impact of malnutrition on taste bud structure has been reported previously (Ohara et al., 1995; Hendricks et al., 2004), suggesting that malnutrition could be another factor contributing to the observed decrease in taste bud size and number in $I L-10^{-1-}$ mice. Patients with diseases associated with inflammation often develop taste abnormalities (Bromley, 2000; Mann, 2002; Harris et al., 2006). Delineating the regulation and function of IL-10 in taste tissues would facilitate our understanding of the mechanisms of taste disorders associated with inflammation.

\section{References}

Adler E, Hoon MA, Mueller KL, Chandrashekar J, Ryba NJ, Zuker CS (2000) A novel family of mammalian taste receptors. Cell 100:693-702. CrossRef Medline

Akira S, Uematsu S, Takeuchi O (2006) Pathogen recognition and innate immunity. Cell 124:783-801. CrossRef Medline

Autschbach F, Braunstein J, Helmke B, Zuna I, Schürmann G, Niemir ZI, Wallich R, Otto HF, Meuer SC (1998) In situ expression of interleukin-10 in noninflamed human gut and in inflammatory bowel disease. Am J Pathol 153:121-130. CrossRef Medline

Bartel DL, Sullivan SL, Lavoie EG, Sévigny J, Finger TE (2006) Nucleoside triphosphate diphosphohydrolase-2 is the ecto-ATPase of type I cells in taste buds. J Comp Neurol 497:1-12. CrossRef Medline

Beutler B, Cerami A (1989) The biology of cachectin/TNF-a primary mediator of the host response. Annu Rev Immunol 7:625-655. CrossRef Medline

Bosschaerts T, Morias Y, Stijlemans B, Hérin M, Porta C, Sica A, Mantovani A, De Baetselier P, Beschin A (2011) IL-10 limits production of pathogenic TNF by M1 myeloid cells through induction of nuclear NF-kappaB p50 member in Trypanosoma congolense infection-resistant C57BL/6 mice. Eur J Immunol 41:3270-3280. CrossRef Medline

Bromley SM (2000) Smell and taste disorders: a primary care approach. Am Fam Physician 61:427-436, 438. Medline

Cao Y, Zhao FL, Kolli T, Hivley R, Herness S (2009) GABA expression in the mammalian taste bud functions as a route of inhibitory cell-to-cell communication. Proc Natl Acad Sci U S A 106:4006-4011. CrossRef Medline

Chandrashekar J, Yarmolinsky D, von Buchholtz L, Oka Y, Sly W, Ryba NJ, Zuker CS (2009) The taste of carbonation. Science 326:443-445. CrossRef Medline

Chaudhari N, Roper SD (2010) The cell biology of taste. J Cell Biol 190:285296. CrossRef Medline

Clapp TR, Stone LM, Margolskee RF, Kinnamon SC (2001) Immunocytochemical evidence for coexpression of Type III IP3 receptor with signaling components of bitter taste transduction. BMC Neurosci 2:6. CrossRef Medline

Cohn ZJ, Kim A, Huang L, Brand J, Wang H (2010) Lipopolysaccharideinduced inflammation attenuates taste progenitor cell proliferation and shortens the life span of taste bud cells. BMC Neurosci 11:72. CrossRef Medline 
Daly K, Al-Rammahi M, Arora DK, Moran AW, Proudman CJ, Ninomiya Y, Shirazi-Beechey SP (2012) Expression of sweet receptor components in equine small intestine: relevance to intestinal glucose transport. Am J Physiol Regul Integr Comp Physiol 303:R199-R208. CrossRef Medline

Donnelly RP, Sheikh F, Kotenko SV, Dickensheets H (2004) The expanded family of class II cytokines that share the IL-10 receptor-2 (IL-10R2) chain. J Leukoc Biol 76:314-321. CrossRef Medline

Feng P, Yee KK, Rawson NE, Feldman LM, Feldman RS, Breslin PA (2009) Immune cells of the human peripheral taste system: dominant dendritic cells and CD4 T cells. Brain Behav Immun 23:760-766. CrossRef Medline

Feng P, Wang H, Feldman RS, Pribitkin EA, Breslin PA (2010) The T cells in peripheral taste tissue of healthy human adults: predominant memory $\mathrm{T}$ cells and Th-1 cells. Chem Senses 35:501-509. CrossRef Medline

Feng P, Zhao H, Chai J, Huang L, Wang H (2012) Expression and secretion of TNF-alpha in mouse taste buds: a novel function of a specific subset of type II taste cells. PLoS One 7:e43140. CrossRef Medline

Feng P, Chai J, Wang H (2013) Differential expression of TNF receptors in subtypes of taste cells. Abstracts from the Thirty-Fourth Annual Meeting of the Association for Chemoreception Sciences. Chem Senses 38:274.

Finger TE (2005) Cell types and lineages in taste buds. Chem Senses 30 [Suppl 1]:i54-55. CrossRef Medline

Frost RA, Nystrom GJ, Lang CH (2002) Lipopolysaccharide regulates proinflammatory cytokine expression in mouse myoblasts and skeletal muscle. Am J Physiol Regul Integr Comp Physiol 283:R698-R709. Medline

Gao N, Lu M, Echeverri F, Laita B, Kalabat D, Williams ME, Hevezi P, Zlotnik A, Moyer BD (2009) Voltage-gated sodium channels in taste bud cells. BMC Neurosci 10:20. CrossRef Medline

Harris R, Davidson TM, Murphy C, Gilbert PE, Chen M (2006) Clinical evaluation and symptoms of chemosensory impairment: one thousand consecutive cases form the dysfunction clinic in San Diego. Am J Rhinol 20:101-108. Medline

Hendricks SJ, Brunjes PC, Hill DL (2004) Taste bud cell dynamics during normal and sodium-restricted development. J Comp Neurol 472:173182. CrossRef Medline

Hevezi P, Moyer BD, Lu M, Gao N, White E, Echeverri F, Kalabat D, Soto H, Laita B, Li C, Yeh SA, Zoller M, Zlotnik A (2009) Genome-wide analysis of gene expression in primate taste buds reveals links to diverse processes. PLoS One 4:e6395. CrossRef Medline

Hoon MA, Adler E, Lindemeier J, Battey JF, Ryba NJ, Zuker CS (1999) Putative mammalian taste receptors: a class of taste-specific GPCRs with distinct topographic selectivity. Cell 96:541-551. CrossRef Medline

Huang L, Shanker YG, Dubauskaite J, Zheng JZ, Yan W, Rosenzweig S, Spielman AI, Max M, Margolskee RF (1999) Ggamma13 colocalizes with gustducin in taste receptor cells and mediates IP3 responses to bitter denatonium. Nat Neurosci 2:1055-1062. CrossRef Medline

Huang YJ, Maruyama Y, Dvoryanchikov G, Pereira E, Chaudhari N, Roper SD (2007) The role of pannexin 1 hemichannels in ATP release and cell-cell communication in mouse taste buds. Proc Natl Acad Sci U S A 104:6436-6441. CrossRef Medline

Kamanaka M, Kim ST, Wan YY, Sutterwala FS, Lara-Tejero M, Galán JE, Harhaj E, Flavell RA (2006) Expression of interleukin-10 in intestinal lymphocytes detected by an interleukin-10 reporter knockin tiger mouse. Immunity 25:941-952. CrossRef Medline

Kataoka S, Baquero A, Yang D, Shultz N, Vandenbeuch A, Ravid K, Kinnamon SC, Finger TE (2012) A2BR adenosine receptor modulates sweet taste in circumvallate taste buds. PLoS One 7:e30032. CrossRef Medline

Kim A, Feng P, Ohkuri T, Sauers D, Cohn ZJ, Chai J, Nelson T, Bachmanov AA, Huang L, Wang H (2012) Defects in the peripheral taste structure and function in the MRL/lpr mouse model of autoimmune disease. PLoS One 7:e35588. CrossRef Medline

Kim MR, Kusakabe Y, Miura H, Shindo Y, Ninomiya Y, Hino A (2003) Regional expression patterns of taste receptors and gustducin in the mouse tongue. Biochem Biophys Res Commun 312:500-506. CrossRef Medline

Kissner TL, Ruthel G, Alam S, Ulrich RG, Fernandez S, Saikh KU (2011) Activation of MyD88 signaling upon staphylococcal enterotoxin binding to MHC class II molecules. PLoS One 6:e15985. CrossRef Medline

Kühn R, Lohler J, Rennick D, Rajewsky K, Müller W (1993) Interleukin-10deficient mice develop chronic enterocolitis. Cell 75:263-274. CrossRef Medline
Li F, Ponissery-Saidu S, Yee KK, Wang H, Chen ML, Iguchi N, Zhang G, Jiang P, Reisert J, Huang L (2013) Heterotrimeric G protein subunit Ggamma13 is critical to olfaction. J Neurosci 33:7975-7984. CrossRef Medline

Livak KJ, Schmittgen TD (2001) Analysis of relative gene expression data using real-time quantitative PCR and the $2-\Delta \Delta \mathrm{Ct}$ method. Methods 25: 402-408. CrossRef Medline

Madan R, Demircik F, Surianarayanan S, Allen JL, Divanovic S, Trompette A, Yogev N, Gu Y, Khodoun M, Hildeman D, Boespflug N, Fogolin MB, Gröbe L, Greweling M, Finkelman FD, Cardin R, Mohrs M, Müller W, Waisman A, Roers A, et al. (2009) Nonredundant roles for B cellderived IL-10 in immune counter-regulation. J Immunol 183:2312-2320. CrossRef Medline

Mann NM (2002) Management of smell and taste problems. Cleve Clin J Med 69:329-336. CrossRef Medline

Matsunami H, Montmayeur JP, Buck LB (2000) A family of candidate taste receptors in human and mouse. Nature 404:601-604. CrossRef Medline

Max M, Shanker YG, Huang L, Rong M, Liu Z, Campagne F, Weinstein H, Damak S, Margolskee RF (2001) Tas1r3, encoding a new candidate taste receptor, is allelic to the sweet responsiveness locus Sac. Nat Genet 28:58 63. CrossRef Medline

Maynard CL, Harrington LE, Janowski KM, Oliver JR, Zindl CL, Rudensky AY, Weaver CT (2007) Regulatory T cells expressing interleukin 10 develop from Foxp3+ and Foxp3- precursor cells in the absence of interleukin 10. Nat Immunol 8:931-941. CrossRef Medline

McLaughlin SK, McKinnon PJ, Margolskee RF (1992) Gustducin is a tastecell-specific G protein closely related to the transducins. Nature 357:563569. CrossRef Medline

Michel G, Mirmohammadsadegh A, Olasz E, Jarzebska-Deussen B, Müschen A, Kemény L, Abts HF, Ruzicka T (1997) Demonstration and functional analysis of IL-10 receptors in human epidermal cells: decreased expression in psoriatic skin, down-modulation by IL-8, and up-regulation by an antipsoriatic glucocorticosteroid in normal cultured keratinocytes. J Immunol 159:6291-6297. Medline

Moore KW, de Waal Malefyt R, Coffman RL, O'Garra A (2001) Interleukin-10 and the interleukin-10 receptor. Annu Rev Immunol 19:683-765. CrossRef Medline

Ohara I, Tabuchi R, Kimura M, Itokawa Y (1995) Decline of taste sensitivity in protein deficient adult rats. Physiol Behav 57:921-926. CrossRef Medline

P'erez CA, Huang L, Rong M, Kozak JA, Preuss AK, Zhang H, Max M, Margolskee RF (2002) A transient receptor potential channel expressed in taste receptor cells. Nat Neurosci 5:1169-1176. CrossRef Medline

Roers A, Siewe L, Strittmatter E, Deckert M, Schlüter D, Stenzel W, Gruber AD, Krieg T, Rajewsky K, Müller W (2004) T cell-specific inactivation of the interleukin 10 gene in mice results in enhanced $\mathrm{T}$ cell responses but normal innate responses to lipopolysaccharide or skin irritation. J Exp Med 200:1289-1297. CrossRef Medline

Saraiva M, O'Garra A (2010) The regulation of IL-10 production by immune cells. Nat Rev Immunol 10:170-181. CrossRef Medline

Sasayama T, Nakamizo S, Nishihara M, Kawamura A, Tanaka H, Mizukawa K, Miyake S, Taniguchi M, Hosoda K, Kohmura E (2012) Cerebrospinal fluid interleukin-10 is a potentially useful biomarker in immunocompetent primary central nervous system lymphoma (PCNSL). Neuro Oncol 14:368-380. CrossRef Medline

Shi L, He L, Sarvepalli P, McCluskey LP (2012) Functional role for interleukin-1 in the injured peripheral taste system. J Neurosci Res 90: 816-830. CrossRef Medline

Shigemura N, Ohta R, Kusakabe Y, Miura H, Hino A, Koyano K, Nakashima K, Ninomiya Y (2004) Leptin modulates behavioral responses to sweet substances by influencing peripheral taste structures. Endocrinology 145: 839-847. CrossRef Medline

Shoelson SE, Lee J, Goldfine AB (2006) Inflammation and insulin resistance. J Clin Invest 116:1793-1801. CrossRef Medline

Sundstedt A, Höiden I, Rosendahl A, Kalland T, van Rooijen N, Dohlsten M (1997) Immunoregulatory role of IL-10 during superantigen-induced hyporesponsiveness in vivo. J Immunol 158:180-186. Medline

Tomonari H, Miura H, Nakayama A, Matsumura E, Ooki M, Ninomiya Y, Harada S (2012) Galpha-gustducin is extensively coexpressed with sweet and bitter taste receptors in both the soft palate and fungiform papillae but has a different functional significance. Chem Senses 37:241251. CrossRef Medline 
Varfolomeev EE, Ashkenazi A (2004) Tumor necrosis factor: an apoptosis JuNKie? Cell 116:491-497. CrossRef Medline

Wang H, Zhou M, Brand J, Huang L (2007) Inflammation activates the interferon signaling pathways in taste bud cells. J Neurosci 27:1070310713. CrossRef Medline

Wang H, Zhou M, Brand J, Huang L (2009a) Inflammation and taste disorders: mechanisms in taste buds. Ann NY Acad Sci 1170:596-603. CrossRef Medline

Wang H, Iguchi N, Rong Q, Zhou M, Ogunkorode M, Inoue M, Pribitkin EA, Bachmanov AA, Margolskee RF, Pfeifer K, Huang L (2009b) Expression of the voltage-gated potassium channel KCNQ1 in mammalian taste bud cells and the effect of its null-mutation on taste preferences. J Comp Neurol 512:384-398. CrossRef Medline

Yoshida R, Ohkuri T, Jyotaki M, Yasuo T, Horio N, Yasumatsu K, Sanematsu
K, Shigemura N, Yamamoto T, Margolskee RF, Ninomiya Y (2010) Endocannabinoids selectively enhance sweet taste. Proc Natl Acad Sci U S A 107:935-939. CrossRef Medline

Zhang Y, Hoon MA, Chandrashekar J, Mueller KL, Cook B, Wu D, Zuker CS, Ryba NJ (2003) Coding of sweet, bitter, and umami tastes: different receptor cells sharing similar signaling pathways. Cell 112:293-301. CrossRef Medline

Zhao FL, Shen T, Kaya N, Lu SG, Cao Y, Herness S (2005) Expression, physiological action, and coexpression patterns of neuropeptide $\mathrm{Y}$ in rat taste-bud cells. Proc Natl Acad Sci U S A 102:11100-11105. CrossRef Medline

Zipp F, Aktas O (2006) The brain as a target of inflammation: common pathways link inflammatory and neurodegenerative diseases. Trends Neurosci 29:518-527. CrossRef Medline 